\title{
Oxygen minimum zone in the North Atlantic south and east of the Cape Verde Islands
}

\author{
Lothar Stramma, ${ }^{1}$ Peter Brandt, ${ }^{1}$ Jens Schafstall, ${ }^{1}$ Friedrich Schott, ${ }^{1}$ Jürgen Fischer, ${ }^{1}$ \\ and Arne Körtzinger ${ }^{1}$ \\ Received 4 June 2007; revised 4 December 2007; accepted 8 January 2008; published 12 April 2008.
}

[1] The open-ocean oxygen minimum zone (OMZ) south and east of the Cape Verde Islands is studied from CTD hydrography, ADCP velocities, Argo float trajectories, and historical data, with a focus on the zonal supply and drainage paths. The strongest oxygen minimum is located north of the North Equatorial Countercurrent (NECC) at about 400 to 500-m depth just above the boundary between Central Water and Antarctic Intermediate Water (AAIW). It is shown that the NECC, the North Equatorial Undercurrent at 4 to $6^{\circ} \mathrm{N}$, and a northern branch of the NECC at 8 to $10^{\circ} \mathrm{N}$ are the sources for oxygen-rich water supplied to the OMZ in summer and fall. A weak eastward NECC at 200-m depth also exists in winter and spring as derived from Argo floats drifting at shallow levels. Historical oxygen data from 200-m depth confirm this seasonality showing high (low) oxygen content in summer and fall (spring) within the supply paths. Compared to the strong oxygen supply at 150 to $300-\mathrm{m}$ depth, the ventilation of the $\mathrm{OMZ}$ at 300 to $600-\mathrm{m}$ depth is weaker. Westward drainage of oxygen-poor water takes place north of the Guinea Dome, i.e., north of $10^{\circ} \mathrm{N}$, most pronounced at 400 to $600-\mathrm{m}$ depth. In July 2006 the total eastward transport of both NECC bands above $\sigma_{\theta}=27.1 \mathrm{~kg} \mathrm{~m}^{-3}$ at $23^{\circ} \mathrm{W}$ was about $13 \mathrm{~Sv}\left(1 \mathrm{~Sv}=10^{6} \mathrm{~m}^{3} \mathrm{~s}^{-1}\right)$. About half of this water volume circulates within the Guinea Dome or recirculates westward north of the Guinea Dome.

Citation: Stramma, L., P. Brandt, J. Schafstall, F. Schott, J. Fischer, and A. Körtzinger (2008), Oxygen minimum zone in the North Atlantic south and east of the Cape Verde Islands, J. Geophys. Res., 113, C04014, doi:10.1029/2007JC004369.

\section{Introduction}

[2] Extended horizontal oxygen minimum zones (OMZs) exist in the eastern tropical Atlantic in the depth range 200 to $800 \mathrm{~m}$. The OMZs are a consequence of a combination of sluggish ocean ventilation, which supplies oxygen, and enhanced respiration, which consumes oxygen [e.g., Karstensen et al., 2008]. Oxygen has been identified as a very sensitive indicator of both physical and biological change in the ocean [Joos et al., 2003]. As a consequence, oxygen is also a key parameter for better understanding the ocean's role in climate [Keeling and Garcia, 2002]. An oxygen decrease had been observed at middepth in repeated hydrographic sections along $24.5^{\circ} \mathrm{N}$ in 1992 compared to 1981 [Garcia et al., 1998], and in fact, model runs suggest a dissolved oxygen decline in the ocean for climate change projections under global warming [e.g., Matear and Hirst, 2003].

[3] In terms of water masses, the core of the North Atlantic OMZ is comprised of Central Water and Antarctic Intermediate Water (AAIW) layers [Stramma et al., 2005]. The OMZ is located between the equatorial current system in the south and the North Equatorial Current (NEC) in the

\footnotetext{
${ }^{1}$ Leibniz-Institut für Meereswissenschaften an der Universität Kiel, IFM-GEOMAR, Kiel, Germany.

Copyright 2008 by the American Geophysical Union. 0148-0227/08/2007JC004369\$09.00
}

north. According to the climatology at 200-m depth [Stramma et al., 2005, Figure 3a], the lowest oxygen values are centered at about $17^{\circ} \mathrm{N}$ east of the Cape Verde Islands near the African continent.

[4] Surface drifter trajectories [Fratantoni, 2001; Lumpkin and Garzoli, 2005] appear to avoid the eastern tropical Atlantic and a lack of drifter data is experienced in the region surrounding the Cape Verde Archipelago. In the subtropical North Atlantic the core of the oxygen minimum is located in the "shadow zone" at the eastern boundary [Luyten et al.,1983; Siedler and Onken, 1996], where the lowest oxygen values observed were about $40 \mu \mathrm{mol} \mathrm{kg}{ }^{-1}$. Hence, different from the suboxic (oxygen content falls below about $4.5 \mu \mathrm{mol} \mathrm{kg}{ }^{-1}$ [e.g., Morrison et al., 1999]) OMZs in the Pacific, the North Atlantic OMZ is hypoxic, based on the relevant criteria. The hypoxic (range $>4.5$ and $<$ about $80 \mu \mathrm{mol} \mathrm{kg}{ }^{-1}$; or $2-3 \mathrm{mg} \mathrm{L}^{-1}$ [Rabalais and Turner, 2001]) conditions have dramatic consequences for the ecosystem as important mobile macroorganisms avoid, or can no longer exist in, the hypoxic layer.

[5] A dominant feature of the eastern tropical Atlantic is the Guinea Dome which covers mainly the Central Water layer. This dome is a permanent, quasi-stationary feature on the eastern side of the thermal ridges extending zonally across the North Atlantic Ocean. The dome is characterized by upward displacement of isotherms in the upper $300 \mathrm{~m}$. The Guinea Dome is centered at $9^{\circ} \mathrm{N}, 25^{\circ} \mathrm{W}$ in boreal summer and $10.5^{\circ} \mathrm{N}, 22^{\circ} \mathrm{W}$ in boreal winter [Siedler et al., 
1992]. In the French $1 / 6^{\circ}$ model the Guinea Dome reaches down to 400-500-m depth [Elmoussaoui et al., 2005]. In the Guinea Dome region there is broad upwelling [Schott et al., 2004, Plate 3], and this upwelling is part of the shallow overturning circulation of the Tropical-Subtropical North Atlantic.

[6] The strong seasonal cycle of the North Equatorial Countercurrent (NECC) [e.g., Richardson and Reverdin, 1987] is related to the annual migration of the Intertropical Convergence Zone [Mayer and Weisberg, 1993]. There is a qualitative relation between the seasonal variability of the wind stress curl forcing over the eastern and western basin and the respective NECC development. East of $25^{\circ} \mathrm{W}$, the depth of the thermocline varies seasonally, but its meridional tilt varies only slightly and does not reverse, and neither does the wind stress curl. By contrast, the thermocline in the west reverses its tilt seasonally, consequently leading to reversal of the baroclinic geostrophic transport, in conjunction with the seasonal reversal of the sign of the wind stress curl field over the NECC [Garzoli and Katz, 1983].

[7] At the locations of the eastward flowing North Equatorial Undercurrent (NEUC) and the NECC relatively high oxygen values are observed [Stramma et al., 2005]. A northern band of the NECC (nNECC) exists at $8^{\circ}$ to $10^{\circ} \mathrm{N}$ [Stramma et al., 2005; Urbano et al., 2006]. Such a separation of the NECC into two separate current cores already was reported earlier from a numerical modeling study of the western equatorial Atlantic [Schott and Böning, 1991]. The nNECC is made up of high-salinity and oxygenrich water from the southern hemisphere, with an admixture from the northern hemisphere. Simulated float trajectories launched north of the Guinea Dome at $13^{\circ} \mathrm{N}, 20-25^{\circ} \mathrm{W}$ at $50-\mathrm{m}$ and $150-\mathrm{m}$ depth and integrated backward in time show that there is strong exchange between the NECC and the $\mathrm{nNECC}$ in the region 22 to $32^{\circ} \mathrm{W}$ [Stramma et al., 2005]. The relaxation of the trade winds in the beginning of the year leads to the generation of equatorial Rossby waves that are associated with the westward propagation of eastward flow north of $4^{\circ} \mathrm{N}$ between March and August. The eastern extension of the NECC into the Gulf of Guinea seems to be a surface flow expression of the Rossby waves [Schouten et al., 2005].

[8] As the NECC approaches the African coast, some of its flow deviates toward the north, resulting in a northward flow referred by some authors as Mauritania Current (MC) [e.g., Mittelstaedt, 1991], responsible for the transfer of warm oligotrophic equatorial water to the tropical eastern Atlantic. The MC shows a seasonal behavior associated with the NECC. In winter and early spring the MC only reaches latitudes of about $14^{\circ} \mathrm{N}$. At this time of the year the wind field off the African coast between $14^{\circ} \mathrm{N}$ and $20^{\circ} \mathrm{N}$ is favorable to coastal upwelling. In summer and early autumn, due to the strengthening of the NECC and the relaxation of the Northeast Trade winds [Lazaro et al., 2005], the $\mathrm{MC}$ reaches latitudes of about $20^{\circ} \mathrm{N}$, just south of Cape Blanc, associated with the cessation of upwelling south of this latitude [Mittelstaedt, 1991]. North of $20^{\circ} \mathrm{N}$ the MC continues, but now as a poleward undercurrent. This upwelling undercurrent partly feeds South Atlantic Central Water properties into the belt of coastal upwelling [Hagen, 2001].
[9] The flow field near the African continent is still not well understood except for the coastal currents in the coastal upwelling regions. According to the surface flow field schematics of the eastern North Atlantic [Mittelstaedt, 1983] there should be a cyclonic circulation to the east of the Cape Verde Islands which reaches south of the Cape Verde Islands in summer, as indicated in Figure 1, while in winter this cell is shifted a bit more to the east and south. The schematic zonal surface flow components are in agreement with the upper ocean velocity distribution on the eastern part of a zonal section in February 1989 at about $14.5^{\circ} \mathrm{N}$, where northward flow was observed near the eastern end of the section off Senegal and southward flow a few hundred kilometers to the west [Klein et al., 1995, Figure 8].

[10] The AAIW layer circulation is less understood than that of the upper ocean. Stramma and Schott [1999] presented an AAIW flow schematic for the tropical Atlantic but noted several open questions and contradicting schemes in the literature for the eastern North Atlantic. From more recent observations, the near-equatorial AAIW current bands, like the eastward flowing Northern and Southern Intermediate Countercurrents (NICC, SICC) and the westward flowing Equatorial Intermediate Current were well resolved [e.g. Brandt et al., 2006].

[11] In this study an investigation of the oxygen distribution in the eastern tropical North Atlantic and of its supply paths is carried out, based on meridional ship sections along about $28^{\circ} \mathrm{W}$ in July/August 2003 and along $23^{\circ} \mathrm{W}$ in July 2006 (Figure 1) as well as on several zonal sections. Using shipboard ADCP and lowered ADCP (LADCP) measurements as well as floats drifting at approximately $200-\mathrm{m}$ and $400-\mathrm{m}$ depth the supply and drainage paths of the OMZ are further specified. Historical data are used to specify the mean oxygen distribution and its seasonality. As the floats were drifting at fixed depths, the horizontal distributions are presented on 200-m and 400-m depth surfaces for easy comparison and not on isopycnal surfaces, which deviate from their mean depth by up to $50 \mathrm{~m}$ in the $\mathrm{OMZ}$ and up to $100 \mathrm{~m}$ outside of the OMZ.

\section{Instruments and Methods}

2.1. Ship Sections: Hydrography and Shipboard ADCP

[12] Two well sampled meridional sections at $23^{\circ} \mathrm{W}$ and about $28^{\circ} \mathrm{W}$ are used to study the zonal supply and export paths of the OMZ. Along $23^{\circ} \mathrm{W}$, the $\mathrm{CTD}-\mathrm{O}_{2}$ data as well as shipboard ADCP data were taken during the R/V Meteor cruise M68/2 in June/July 2006. An additional station was taken at the location of the newly established Cape Verdean time series site, just north of the Cape Verde Islands, at $17^{\circ} 36^{\prime} \mathrm{N}, 24^{\circ} 15^{\prime} \mathrm{W}$ (see Figure 1). The CTD system used during this cruise was a Seabird CTD system with a Seabird oxygen sensor with dual sensor sets. After applying the two independent calibrations to the sensors the temperature readings differed by less than $\pm 0.001{ }^{\circ} \mathrm{C}$. The $\mathrm{CTD}$ salinity was calibrated to a precision of \pm 0.002 by analyzing water samples with an Autosal salinometer. Oxygen from the bottle samples was determined by the Winkler titration method with an rms difference of the CTD oxygen sensor of $\pm 1.3 \mu \mathrm{mol} \mathrm{kg} \mathrm{kg}^{-1}$. Two vessel-mounted RDI Ocean 


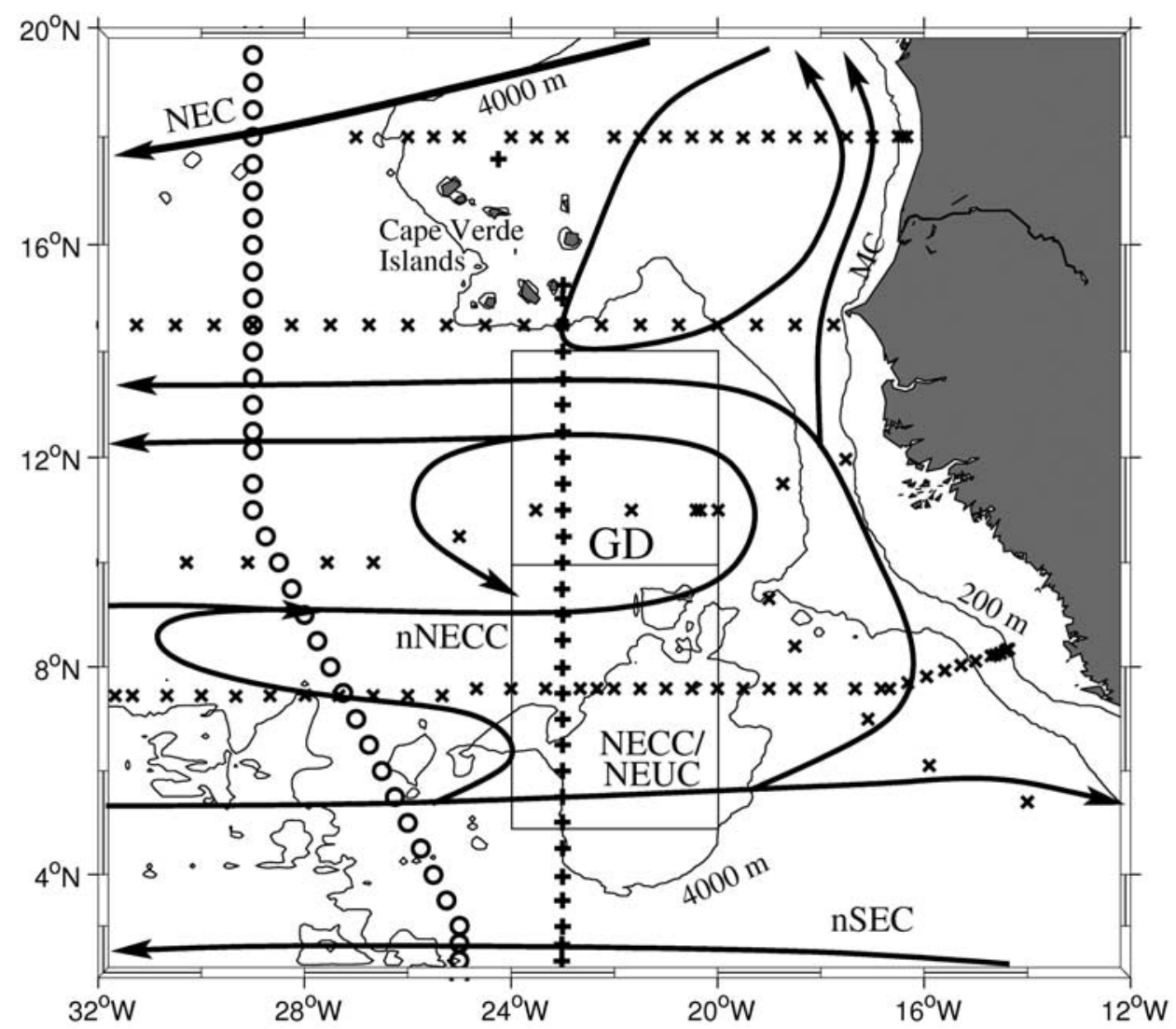

Figure 1. Map of the study area with depth contours of $200 \mathrm{~m}$ and $4000 \mathrm{~m}$ included. Shown are the R/V Ronald H. Brown stations in July/August 2003 (circles) and the R/V Meteor (M68/2; 2-8 July 2006) stations by plus signs. Zonal sections (all marked by crosses) are along $18^{\circ} \mathrm{N}$ from cruise M68/3 (July 2006), along $14.5^{\circ} \mathrm{N}$ from R/V Meteor cruise M9 in February 1989 , along $10^{\circ}$ to $11^{\circ} \mathrm{N}$ plus some stations on the transit toward the southeast from R/V Meteor cruise M55 in October/November 2002 and along $7.5^{\circ} \mathrm{N}$ from R/V l'Atalante cruise in February/March 1993. Two boxes mark the areas used for a seasonal investigation. Included is a schematic of the large scale near-surface flow field (after Stramma et al. [2005] and Mittelstaedt [1983]) as solid lines. Marked are the North Equatorial Current (NEC), the Mauritania Current (MC), the North Equatorial Countercurrent (NECC) connected to the North Equatorial Undercurrent (NEUC), the northern NECC (nNECC), the northern band of the South Equatorial Current (nSEC) as well as the Guinea Dome (GD).

Surveyor ADCPs had been in use (75 kHz, OS75 and $38 \mathrm{kHz}, \mathrm{OS} 38)$. Both units worked in narrowband mode, delivering current velocity to depths of up to $750 \mathrm{~m}$ (OS75) and $1200 \mathrm{~m}$ (OS38), respectively. Ship's heading and position, obtained from GPS (Ashtech) were used to calculate absolute currents, with uncertainties estimated to $1-3 \mathrm{~cm} \mathrm{~s}^{-1}$ for hourly averages. The absolute currents were interpolated to a regular grid, using a Gaussian weighted interpolation scheme.

[13] Hydrographic data from R/V Ronald H. Brown (cruise 33RO200306_02) taken during 15 July to 11 August 2003 along about $2 \overline{8}^{\circ} \mathrm{W}$ were made available through the CLIVAR and Carbon Hydrographic Data Office. While the shipbord ADCP data of the upper $300 \mathrm{~m}$ from that cruise were already shown by Stramma et al. [2005], the deeperreaching LADCP data are presented here to investigate the currents in relation to the oxygen distribution. The CTD- $\mathrm{O}_{2}$ profiles were measured by a Seabird 9plus CTD. The CTD salinity was calibrated from water samples analyzed with the ship's Autosal salinometer. The oxygen data are con- sidered accurate to between \pm 1 and $\pm 7 \mu \mathrm{mol} \mathrm{kg}{ }^{-1}$ [Johnson and Gruber, 2007].

[14] In addition, upper ocean currents (surface to 300-m depth) were obtained from a R/V Polarstern transit from Antarctica along $23^{\circ} \mathrm{W}$ taken during 7-11 June 2005 and extending from the equator to $18^{\circ} \mathrm{N}$. No CTD station work was carried out during this transit. Currents were measured by an RDI Ocean Surveyor ADCP (150 kHZ, OS150) and postprocessing was performed in the same manner as for the $\mathrm{R} / \mathrm{V}$ Meteor cruise.

[15] Four zonal sections are used here, as well. First, a section along about $18^{\circ} \mathrm{N}$ from $27^{\circ} \mathrm{W}$ toward the African shelf, taken by R/V Meteor (cruise M68/3) during 12 July to 6 August 2006 (Figure 1). The same CTD, oxygen and ADCP equipment as on the previous leg M68/2 were used, and the accuracies described above apply also for this cruise. Second, a section along $14.5^{\circ} \mathrm{N}$ is available from $\mathrm{R} / \mathrm{V}$ Meteor cruise 9 during 9-15 February 1989. For this cruise no CTD oxygen is available. However, the oxygen bottle samples were quite accurate and will be shown here. 

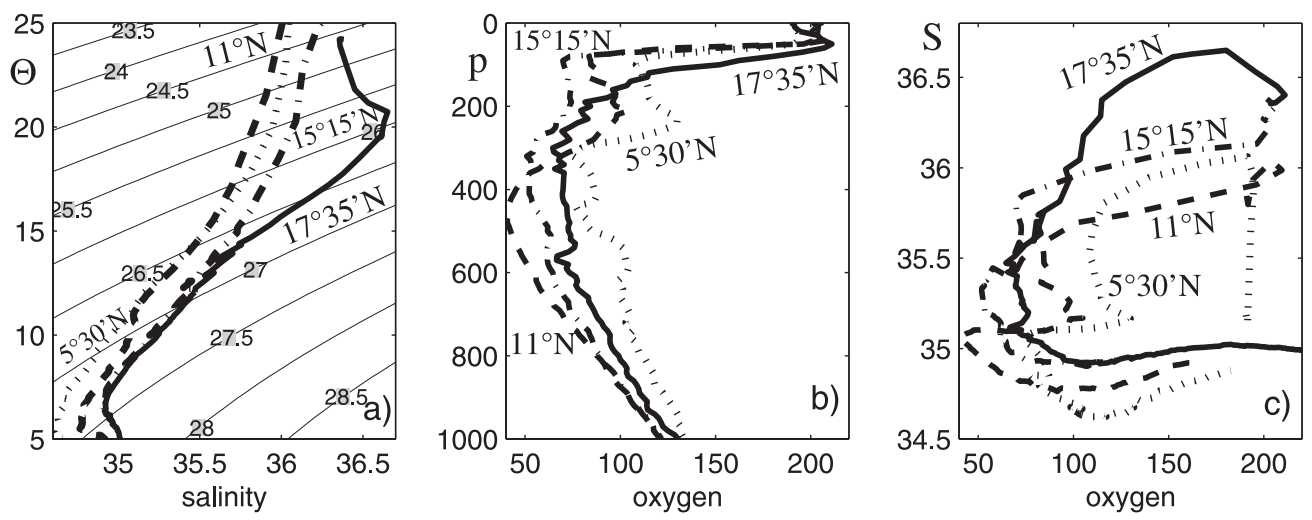

Figure 2. Property-property plots for CTD stations taken in July 2006 along the $23^{\circ} \mathrm{W}$ section at $5^{\circ} 30^{\prime} \mathrm{N}$ (dotted), at $11^{\circ} \mathrm{N}$ (dashed), at $15^{\circ} 15^{\prime} \mathrm{N}$ near the southern Cape Verde Islands (dash-dotted) and one station just north of the Cape Verde Islands at $17^{\circ} 35^{\prime} \mathrm{N}, 24^{\circ} 15^{\prime} \mathrm{W}$ (solid) for (a) the potential temperature-salinity diagram, (b) the oxygen distribution (in $\mu \mathrm{mol} \mathrm{kg}{ }^{-1}$ ) versus pressure (in dbar), and (c) the oxygen

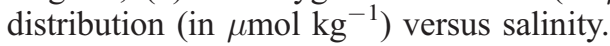

Third, a trans-Atlantic zonal section along about $7^{\circ} 30^{\prime} \mathrm{N}$ was carried out by R/V l'Atalante in February and March 1993 [Arhan et al., 1998]. For the hydrographic stations a Neil Brown Mark III CTD-O 2 system was used. For velocity measurements an RDI $75 \mathrm{kHz}$ VM-ADCP provided currents from $28 \mathrm{~m}$ down to about $700 \mathrm{~m}$ [Marin and Gouriou, 2000]. Finally, a section along about $10-11^{\circ} \mathrm{N}$ is available from R/V Meteor cruise M55, together with a short, mid-ocean meridional excursion to the equator. The CTD profiles were limited to the upper ocean, down to about 650-m depth, and the CTD oxygen sensor was unstable and hence these data are not used here. The oxygen measurements from bottle samples [Wallace and Bange, 2004] will be used here together with the OS75 ADCPvelocities [Stramma et al., 2005]. After finishing the 10$11^{\circ} \mathrm{N}$ section, R/V Meteor headed southeastward toward Duala and a few additional bottle stations and shipboard ADCP data were taken north of $6^{\circ} \mathrm{N}$ (Figure 1).

\subsection{Horizontal Distributions}

[16] Twelve profiling Argo floats were deployed in the western tropical Atlantic to support the studies of the shallow tropical circulation [e.g., Schott et al., 2002, Figure $3]$. These floats were ballasted to drift at 200-m depth. They profiled the upper $2000 \mathrm{~m}$ at regular $10 \mathrm{~d}$ intervals with temperature and salinity profiles being measured by a Seabird CTD. In addition six other $200 \mathrm{~m}$ floats in the region were identified in the freely available Argo data base and were added to our data set. A few floats ballasted to drift at about 400-m depth had been deployed in the western tropical Atlantic. Only one of these floats entered the region investigated here as well as one float deployed in 2007 north of the Cape Verde Islands that drifted within the investigation area.

[17] For historical hydrographic data the hydrobase-2 data set [Curry, 1996] was used for studying the oxygen distribution at $200-\mathrm{m}$ and $400-\mathrm{m}$ depth. In addition, two boxes were defined between $20^{\circ} \mathrm{W}$ and $24^{\circ} \mathrm{W}$, the southern box for $5-10^{\circ} \mathrm{N}$ and the northern one for $10-14^{\circ} \mathrm{N}$ (Figure 1). Only oxygen data collected since 1961 were used to define the annual cycle of the two boxes because older oxygen data in the historical records are rare and introduce larger uncertainties due to different analytical methods applied.

\section{Oxygen Minimum Zone South of the Cape Verde Islands}

\subsection{Water Masses and Oxygen Characteristics}

[18] The water masses in the upper northeastern tropical Atlantic are made up of Tropical Surface Water (TSW; $\sigma_{\theta}<$ $\left.25.8 \mathrm{~kg} \mathrm{~m}^{-3}\right)$, of Central Water $\left(\sigma_{\theta}=25.8\right.$ to $\left.27.1 \mathrm{~kg} \mathrm{~m}^{-3}\right)$, and of AAIW $\left(\sigma_{\theta}=27.1 \mathrm{~kg} \mathrm{~m}^{-3}\right.$ to $\left.\sigma_{1}=32.15 \mathrm{~kg} \mathrm{~m}^{-3}\right)$ [e.g., Stramma et al., 2005]. The Cape Verde Frontal Zone located just north of the Cape Verde Islands separates the more saline North Atlantic Central Water (NACW) from the less saline South Atlantic Central Water (SACW). Property diagrams from four selected stations of the $23^{\circ} \mathrm{W}$ section are shown in Figure 2a. The Central Water had lower salinity for the two southern stations compared to the two stations located just south and north of the Cape Verde Islands. However, there are no associated north-south changes visible in the oxygen profiles of the same stations in this salinity range (35.0-35.6; Figure $2 b)$. The salinity minimum of the AAIW is strongest for the southernmost station presented and a clear increase of the AAIW salinity is present for the stations further north (Figure 2a). A subsurface salinity maximum of the Salinity Maximum Water (SMW) at temperatures of about $20^{\circ} \mathrm{C}$ is seen only for the station north of the Cape Verde Islands. The salinityoxygen relation (Figure 2c) shows that the oxygen minimum is located between salinities of 35 at the southern stations and 35.5 at the northern stations due to the different Central Water masses.

[19] Different regions of the OMZ are represented by the four oxygen profiles (Figure $2 \mathrm{~b}$ ). The profile at $5^{\circ} 30^{\prime} \mathrm{N}$ is located in the eastward flow region of the NECC/NEUC and shows the enhanced oxygen values representing the supply path of oxygen. The profile at $11^{\circ} \mathrm{N}$ shows the lowest middepth oxygen value of the $23^{\circ} \mathrm{W}$ section. Just south of the Cape Verde Islands, at $15^{\circ} 15^{\prime} \mathrm{N}$, the oxygen content below 400-m depth has increased, while at shallower depths the oxygen content is lower than in the other profiles, identifying the circulation cell east of the Cape 

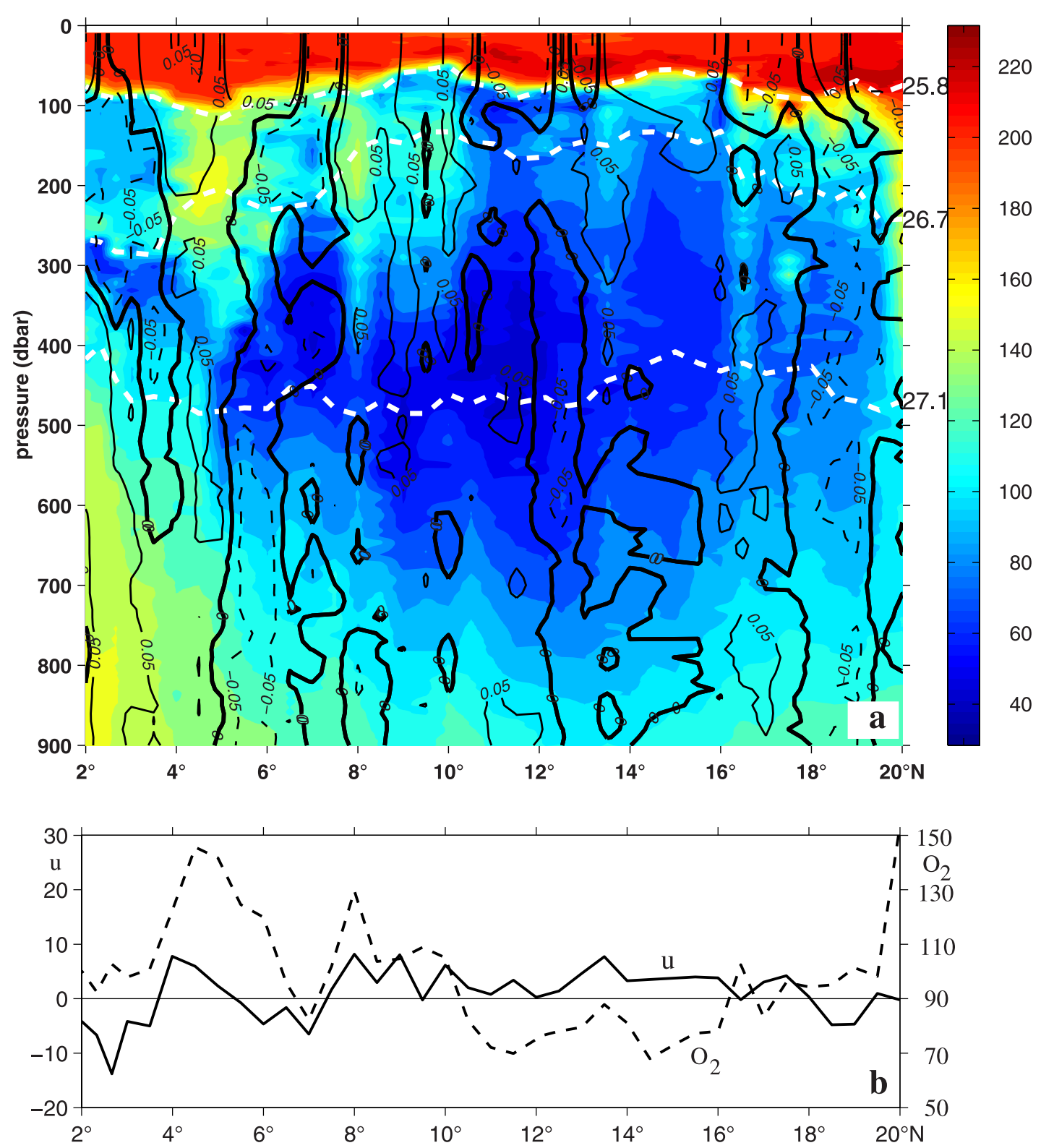

Figure 3. Distribution along the $28^{\circ} \mathrm{W}$ R/V Ronald H. Brown section in July/August 2003 of (a) oxygen ( $\mu \mathrm{mol} \mathrm{kg}^{-1}$, color) and zonal velocity from LADCP (in $\mathrm{m} / \mathrm{s}$, positive eastward) and (b) the 150 to $300 \mathrm{~m}$ means of zonal velocity in $\mathrm{cm} \mathrm{s}^{-1}$ (solid line, positive eastward) as well as of oxygen content (dashed line). Water mass boundaries (dashed white lines) are shown in Figure 3a by the isopycnals $\sigma_{\theta}=25.8$ and $27.1 \mathrm{~kg} \mathrm{~m}^{-3}$, while $26.7 \mathrm{~kg} \mathrm{~m}^{-3}$ represents an additional potential density surface in the Central Water.

Verde Islands. North of the Cape Verde Islands, at $17^{\circ} 35^{\prime} \mathrm{N}$, the entire upper ocean oxygen profile shows higher oxygen values compared to $15^{\circ} 15^{\prime} \mathrm{N}$, indicating the northward extent of the OMZ.

\subsection{OMZ in Ship Sections}

[20] Along the $28^{\circ} \mathrm{W}$ section of July/August 2003 the NECC/NEUC current band at $4-5^{\circ} \mathrm{N}$ and the nNECC band at $8-10^{\circ} \mathrm{N}$ were well developed and associated with water masses of relatively high oxygen content (Figure $3 \mathrm{a}$ ). This relation is well manifested in the mean $150-300 \mathrm{~m}$ velocity and oxygen distributions (Figure $3 b$ ). The two eastward current bands associated with higher oxygen values display that the upper parts of the two NECC current bands supply water with high oxygen content while the deeper parts of the NEUC and NECC contribute only weakly to the oxygen supply. In contrast, low oxygen water is carried westward by the northern branch of the South Equatorial Current (nSEC); it is, however, confined to the upper $400 \mathrm{~m}$ south of $4^{\circ} \mathrm{N}$.

[21] The OMZ along $23^{\circ} \mathrm{W}$ in July 2006 covers the area from $6^{\circ} 20^{\prime} \mathrm{N}$ to the Cape Verde Islands with a layer of less than $60 \mu \mathrm{mol} \mathrm{kg}^{-1}$. The isopycnal $\sigma_{\theta}=27.1 \mathrm{~kg} \mathrm{~m}^{-3}$ that divides Central Water and AAIW cuts through the core of the oxygen minimum (Figure $4 \mathrm{a}$ ). The comparison of the 


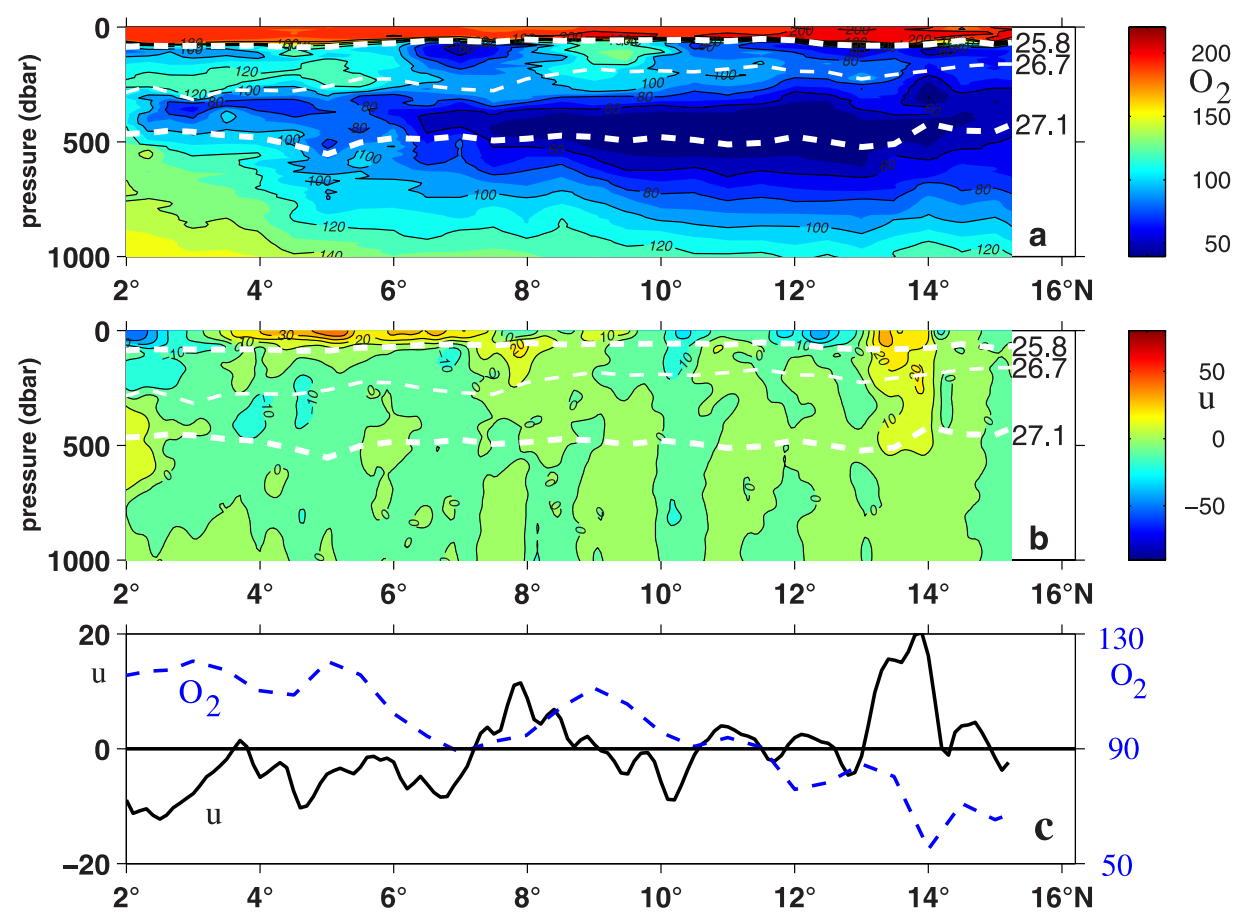

Figure 4. Distribution along the $23^{\circ} \mathrm{W}$ section in July 2006 of (a) oxygen ( $\mu$ mol kg ${ }^{-1}$, color) with a contour interval of $20 \mu \mathrm{mol} \mathrm{kg}^{-1}$, (b) zonal velocity from shipboard ADCP (in $\mathrm{cm} \mathrm{s}^{-1}$ ), and (c) the 150 to $300 \mathrm{~m}$ means of zonal velocity in $\mathrm{cm} \mathrm{s}^{-1}$ (solid line, positive eastward) as well as of oxygen content in $\mu \mathrm{mol} \mathrm{kg} \mathrm{kg}^{-1}$ (dashed line). Water mass boundaries (dashed white lines) are shown in Figures $4 \mathrm{a}$ and $4 \mathrm{~b}$ by the isopycnals $\sigma_{\theta}=25.8$ and $27.1 \mathrm{~kg} \mathrm{~m}^{-3}$, while $26.7 \mathrm{~kg} \mathrm{~m}^{-3}$ represents an additional potential density surface in the Central Water.

oxygen distribution with the ADCP-derived distribution of zonal velocities (Figure 4b) shows a connection between higher oxygen and the NECC/NEUC at about $5^{\circ} \mathrm{N}$ and the nNECC at $8^{\circ} \mathrm{N}$ to $10^{\circ} \mathrm{N}$ although not as well established as along $28^{\circ} \mathrm{W}$. It is possible that this farther east the currents are not well established all the time and that mesoscale eddies dominate the flow field. At $5-6^{\circ} \mathrm{N}$ the NECC reaches only to $250-\mathrm{m}$ depth and is connected to high oxygen values. The nNECC at $8-10^{\circ} \mathrm{N}$ is associated with higher oxygen values in the upper $300 \mathrm{~m}$ which leads to a reduced vertical extent of the OMZ below 300-m depth. Westward flow north of $10^{\circ} \mathrm{N}$ drains water out of the OMZ, at a location where the $\mathrm{OMZ}$ is deepest. North of $10^{\circ} \mathrm{N}$ no clear current direction is observed and alternating directions point to eddy activity.

[22] The lowest mean oxygen values at $28^{\circ} \mathrm{W}$ for the 150 to $300 \mathrm{~m}$ layer are observed between $10^{\circ} \mathrm{N}$ and $16^{\circ} \mathrm{N}$ although the corresponding mean LADCP velocity component still shows a weak eastward component. An enhanced eastward flow at $13.5^{\circ} \mathrm{N}$ is again associated with higher mean oxygen values. North of $16^{\circ} \mathrm{N}$ the mean oxygen increases (Figure $3 \mathrm{~b}$ ) as the area of the southern extent of the North Equatorial Current (NEC) is encountered with a strong oxygen front at $20^{\circ} \mathrm{N}$. In the 150 to $300 \mathrm{~m}$ layer south of the NEUC region at $23^{\circ} \mathrm{W}$ (Figure 4c) the oxygen content is still high although in July 2006 the 150 to $300 \mathrm{~m}$ layer transport of the NEUC hardly reaches a positive vertical mean. As the oxygen concentration is an integral measure of longer time periods the decrease in oxygen content north of $6^{\circ} \mathrm{N}$ indicates the general oxygen-richer water supply by the NEUC to the south of $6^{\circ} \mathrm{N}$. The nNECC at 8 to $9^{\circ} \mathrm{N}$ is represented by a positive mean transport in the 150 to $300-\mathrm{m}$ depth layer related to a clear increase in oxygen. In the region north of $10^{\circ} \mathrm{N}$ the lowest 150 to 300 $\mathrm{m}$ oxygen mean is reached at $14^{\circ} \mathrm{N}$. This is surprisingly located north of an eastward current band. However, according to the summer flow field of Mittelstaedt [1983] the $23^{\circ} \mathrm{W}$ section crosses a cyclonic circulation located to the east and south of the Cape Verde Islands. The lowest oxygen values are located off the coast of Africa and the circulation cell east and south of the Cape Verde Islands carries the lowest oxygen poor water, leading to the unusual eastward transport of oxygen-poor water.

[23] A direct comparison of the $28^{\circ} \mathrm{W}$ and $23^{\circ} \mathrm{W}$ section means of the 300 to $600-\mathrm{m}$ layer shows many similarities due to the dominance of the zonal current bands in the central eastern tropical North Atlantic. The curves of the layer mean oxygen content (Figure 5) are of similar shape with the more easterly section showing lower oxygen content between $6^{\circ} \mathrm{N}$ and $15^{\circ} \mathrm{N}$ as this section is located closer to the core of the $\mathrm{OMZ}$. At $28^{\circ} \mathrm{W}$ the strong eastward current bands of the NICC at $2^{\circ} \mathrm{N}$ and the NEUC at $4-5^{\circ} \mathrm{N}$ are connected to high mean oxygen values, while the lower nNECC at 8 to $10^{\circ} \mathrm{N}$ shows only a small region of enhanced oxygen at about $8^{\circ} \mathrm{N}$. Although the oxygen distribution at $23^{\circ} \mathrm{W}$ in the 300 to $600 \mathrm{~m}$ layer indicates an oxygen supply the transport of the NEUC hardly reaches a positive mean (Figure 5). The nNECC at 9 to $10^{\circ} \mathrm{N}$ is represented by a positive mean transport and the northward decrease in 


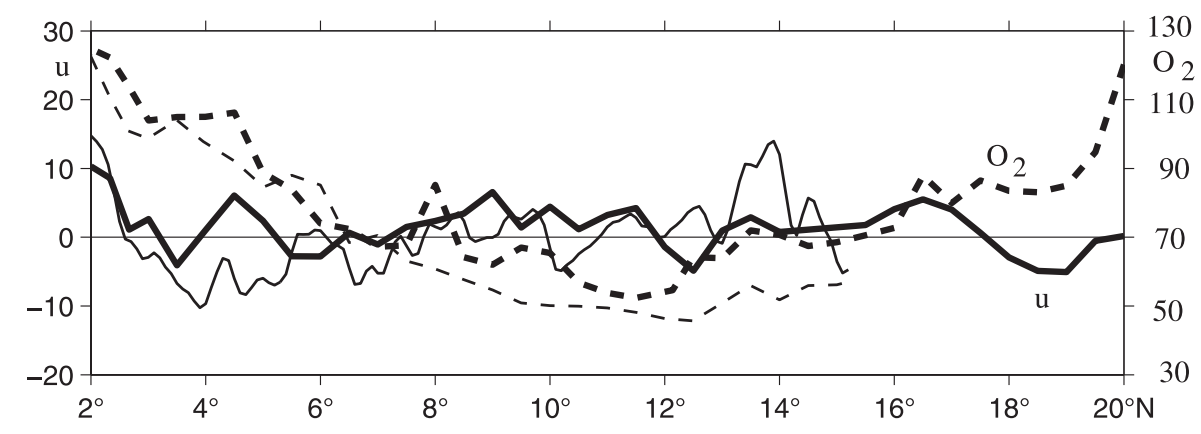

Figure 5. Distribution of the mean velocity $\left(\mathrm{cm} \mathrm{s}^{-1}\right)$ of the $300-600-\mathrm{m}$ depth layer along the $28^{\circ} \mathrm{W}$ section in July/August 2003 (thick solid line, positive eastward) and along the $23^{\circ} \mathrm{W}$ section in July 2006 (thin solid line) as well as the mean oxygen content of this layer $\left(\mu \mathrm{mol} \mathrm{kg}{ }^{-1}\right)$ for $28^{\circ} \mathrm{W}$ (thick dashed line) and for $23^{\circ} \mathrm{W}$ (thin dashed line).

oxygen is only reduced. At $28^{\circ} \mathrm{W}$ the westward flow north of $18^{\circ} \mathrm{N}$ is connected to strongly increasing oxygen content. [24] In the AAIW layer below $\sigma_{\theta}=27.1 \mathrm{~kg} \mathrm{~m}^{-3}$ the largest eastward velocities are present at $2^{\circ}-3^{\circ} \mathrm{N}$ at $28^{\circ} \mathrm{W}$, which is the signature of the NICC. Float observations showed that the zonal flows in the AAIW layer like the NICC are coherent longitudinally over the range of nearly $3000 \mathrm{~km}$ [Ollitrault et al., 2006], with enhanced oxygen content being connected to the NICC (Figure 3a). A similar relation is visible in a March/April 2000 meridional section crossing the equator at $23^{\circ} \mathrm{W}$ south of $4^{\circ} \mathrm{N}$ with the NICC located at $0.5^{\circ}-2.5^{\circ} \mathrm{N}$ and large oxygen values present in the corresponding area [Stramma et al., 2003, Figures 2 and 4]. In summary, AAIW originates in the southern hemisphere and progresses northward, with the NICC as the major source of oxygen supply for the AAIW layer of the OMZ, especially in the deeper part of the AAIW layer.

[25] The circulation plays a major role in maintaining the structure of the OMZ. A comparison for the upper $300 \mathrm{~m}$ of the ADCP velocity distribution at $23^{\circ} \mathrm{W}$ in June 2005 (Figure 6a) and July 2006 (Figure 6b) shows similarities as well as differences for the two coverages seperated by 13 months. The deeper part of the NECC (below $100 \mathrm{~m}$ ) clearly showed two distinct NECC bands located at $6^{\circ} \mathrm{N}$ and $9^{\circ} \mathrm{N}$ in the 2005 observations; different from the situation in 2006. Near the surface, this separation is not observed, and the NECC is one broad current band in the upper $80 \mathrm{~m}$ for both surveys. However, in June 2005, the northern band of the SEC extends farther north and the NECC is located north of $5^{\circ} \mathrm{N}$, almost $2^{\circ}$ farther north than in July 2006. The eastward flow at 13 to $14^{\circ} \mathrm{N}$ is present in both surveys while the westward flow at 12 to $13^{\circ} \mathrm{N}$ is stronger and reaching deeper in June 2005 compared to July 2006.

[26] To derive a more quantitative view of the current bands maintaining the supply of the oxygen to the OMZ, the shipboard ADCP transports were computed for the July $200623^{\circ} \mathrm{W}$ section (Figure 6b). As the transports are small, their components are summed up in tenths of a Sverdrup, albeit the instrumental errors will be of similar order. The nSEC between $2^{\circ} \mathrm{N}$ and the NECC carries $5.9 \mathrm{~Sv}(1 \mathrm{~Sv}=$ $10^{6} \mathrm{~m}^{3} \mathrm{~s}^{-1}$ ) westward above $\sigma_{\theta}=26.7 \mathrm{~kg} \mathrm{~m}^{-3}$. Although the eastward flowing $\mathrm{NICC}$ is cut at $2^{\circ} \mathrm{N}$, the part of the NICC located north of $2^{\circ} \mathrm{N}$ sums up to $2.8 \mathrm{~Sv}$. The two bands of the NECC are divided in two parts at $7^{\circ} \mathrm{N}$. For the layer between the sea surface and $\sigma_{\theta}=25.8 \mathrm{~kg} \mathrm{~m}^{-3}$ the eastward transport is $6.1 \mathrm{~Sv}$ south of $7^{\circ} \mathrm{N}$ and $1.9 \mathrm{~Sv}$ between 7 and $10^{\circ} \mathrm{N}$. The NEUC at $4^{\circ} \mathrm{N}$ to $6^{\circ} \mathrm{N}$ is almost absent. The deeper part of the nNECC shows much stronger eastward flows for the same layers. The total eastward transport of the NECC system is $12.8 \mathrm{~Sv}$ above $\sigma_{\theta}=27.1 \mathrm{~kg} \mathrm{~m}^{-3}$. Lazaro et al. [2005] derived a maximum NECC transport at $25^{\circ} \mathrm{W}$ in June of $12.9 \pm 2.4 \mathrm{~Sv}$, hence almost identical to the transport at $23^{\circ} \mathrm{W}$ in July 2006 .

[27] Most of the water recirculating westward north of $10^{\circ} \mathrm{N}$ progresses westward along the isothermal ridge. Only a small fraction seems to be trapped within a closed circulation, the Guinea Dome, and we have no data to determine the fraction of the closed circulation. Here we name the westward flow north of $10^{\circ} \mathrm{N}$ the Guinea Dome transport, although it is really a measure of the recirculating NECC water. The transport of the Guinea Dome is $3.1 \mathrm{~Sv}$ for the layer from the sea surface to the isopycnal $\sigma_{\theta}=25.8 \mathrm{~kg} \mathrm{~m}^{-3}$ and $6.5 \mathrm{~Sv}$ from the surface to the isopycnal $\sigma_{\theta}=27.1 \mathrm{~kg} \mathrm{~m}^{-3}$ (Figure 6b). Similar transport values were estimated for a zonal $\mathrm{R} / \mathrm{V}$ Meteor section in October/November 2002 along about $11^{\circ} \mathrm{N}$ of $2.8 \mathrm{~Sv}$ for the upper layer and $4.0 \mathrm{~Sv}$ for the $\sigma_{\theta}=25.8$ to $27.1 \mathrm{~kg} \mathrm{~m}^{-3}$ layer [Stramma et al., 2005]. In November 2002 there was an additional ADCP section at about $24^{\circ} \mathrm{W}$ between the equator and $11^{\circ} \mathrm{N}$, which can be used for transport comparisons with the $23^{\circ} \mathrm{W}$ section. The eastward current bands are similar for the November 2002 and the July 2006 cruises. The total NECC eastward transport between the surface and $\sigma_{\theta}=25.8 \mathrm{~kg} \mathrm{~m}^{-3}$ was $8.0 \mathrm{~Sv}$ in July 2006 and 7.2 Sv in November 2002.

[28] In the northern part of the $\mathrm{OMZ}$ an $\mathrm{R} / \mathrm{V}$ Meteor section was made just to the south of the Cape Verde Islands along $14.5^{\circ} \mathrm{N}$ in February 1989. The oxygen distribution was only available from bottle data. The Cape Verde Islands north of this section are located at about $23^{\circ} \mathrm{W}$ to $25^{\circ} \mathrm{W}$. East of $24^{\circ} \mathrm{W}$ the oxygen minimum of the $14.5^{\circ} \mathrm{N}$ section is distinct, while to the west the oxygen values in the core of the $\mathrm{OMZ}$ increase except for two limited minimum zones of less than $60 \mu \mathrm{mol} \mathrm{kg}{ }^{-1}$ at $25.5^{\circ} \mathrm{W}$ and at $27^{\circ} \mathrm{W}$ to $29^{\circ} \mathrm{W}$ (Figure 7). The latter minimum is probably the signature of a current band of the circulation cell located mainly east of the Cape Verde Islands as indicated in the circulation schematics of Mittelstaedt [1983]. The lowest oxygen values of less than $50 \mu \mathrm{mol} \mathrm{kg}{ }^{-1}$ were located near the African shelf at $18^{\circ} \mathrm{W}$ to $20^{\circ} \mathrm{W}$. 

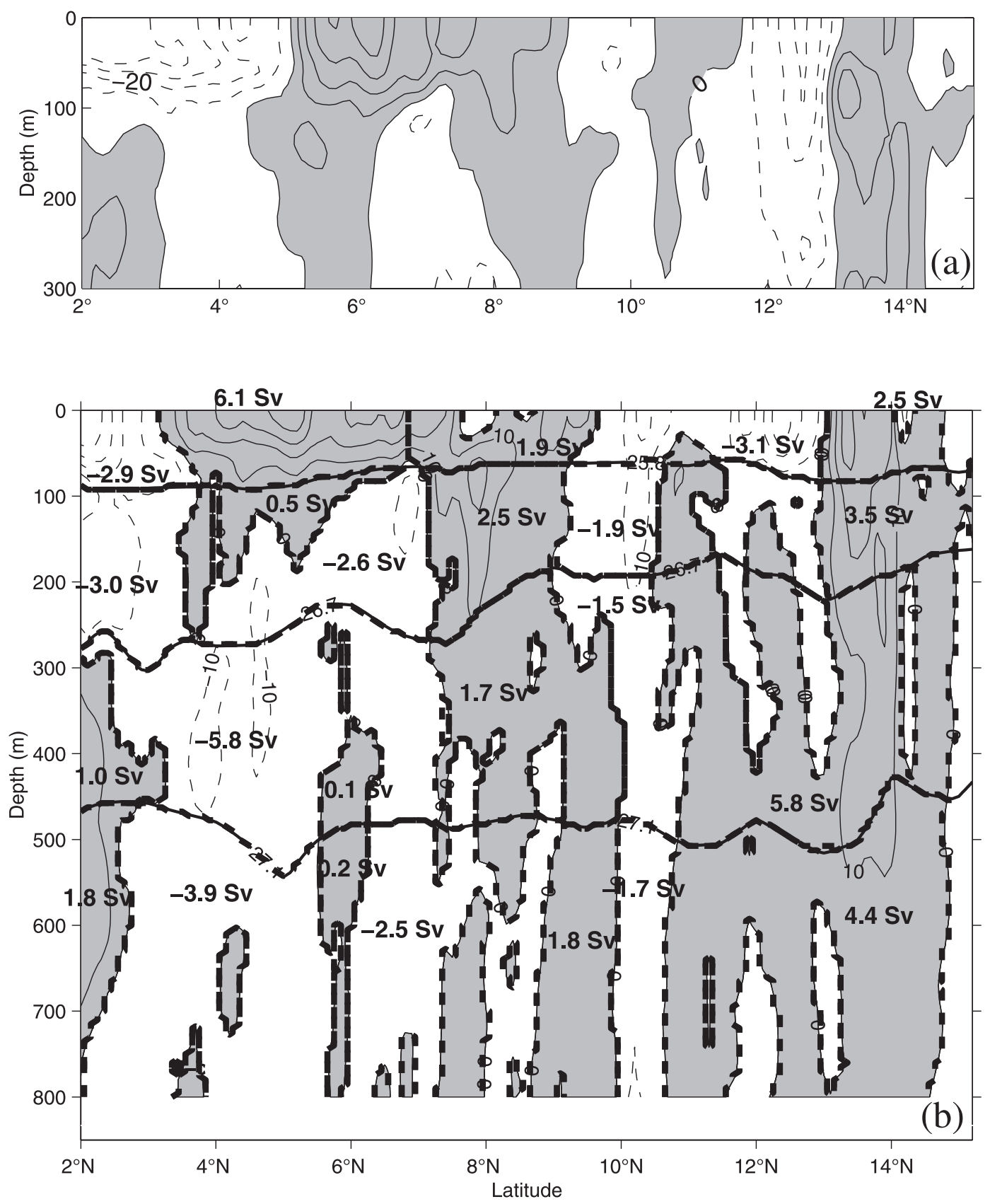

Figure 6. Zonal velocity distribution derived from shipboard ADCP $\left(\mathrm{cm} \mathrm{s}^{-1}\right)$ along the $23^{\circ} \mathrm{W}$ section with a contour interval of $10 \mathrm{~cm} \mathrm{~s}^{-1}$ for (a) the upper $300 \mathrm{~m}$ in June 2005 and (b) in July 2006. Transports in Sv in Figure 6b between the density layers $\left(25.8,26.7\right.$ and $27.1 \mathrm{~kg} \mathrm{~m}^{-3}$ ) or down to $800 \mathrm{~m}$ are shown as solid numbers. Transport integration boundaries are marked by thick dashed lines.

\subsection{Supply Paths From Float and ADCP Observations}

[29] Most of the available shallow Argo floats are drifting at 200-m depth and the float trajectories will be used to further investigate the flow field of the upper OMZ. The float trajectories roughly follow the two NECC cores, the southern flow at about $4-6^{\circ} \mathrm{N}$ and the nNECC at $8-10^{\circ} \mathrm{N}$ (Figure 8, red lines are eastward). There are several westward reversals in the NECC, and the mean zonal velocity between $18^{\circ} \mathrm{W}$ and $28^{\circ} \mathrm{W}$ (Figure 8 , right frame) is eastward only at $4^{\circ} \mathrm{N}$ to $5^{\circ} \mathrm{N}$. The flow north of $10^{\circ} \mathrm{N}$ marks the westward export of $\mathrm{OMZ}$ water. One of the westward drifting floats north of $10^{\circ} \mathrm{N}$ later recirculates south and then eastward again, hence thereby completely cycling around the Guinea Dome.

[30] A stagnation area southwest of the Cape Verde Islands has been described from a float path at $200 \mathrm{~m}$ where one of the floats stayed for more than 3 years in the oxygen minimum zone. That float slowly circled near $12^{\circ} \mathrm{N}$, $27^{\circ} \mathrm{W}$ and finally progressed toward the Cape Verde Islands [Stramma et al., 2005], where it quit transmitting after a lifetime of more than 5 years. It is worth noting that none of the floats deployed in the tropical western Atlantic made its way into the region east and southeast of the Cape Verde 


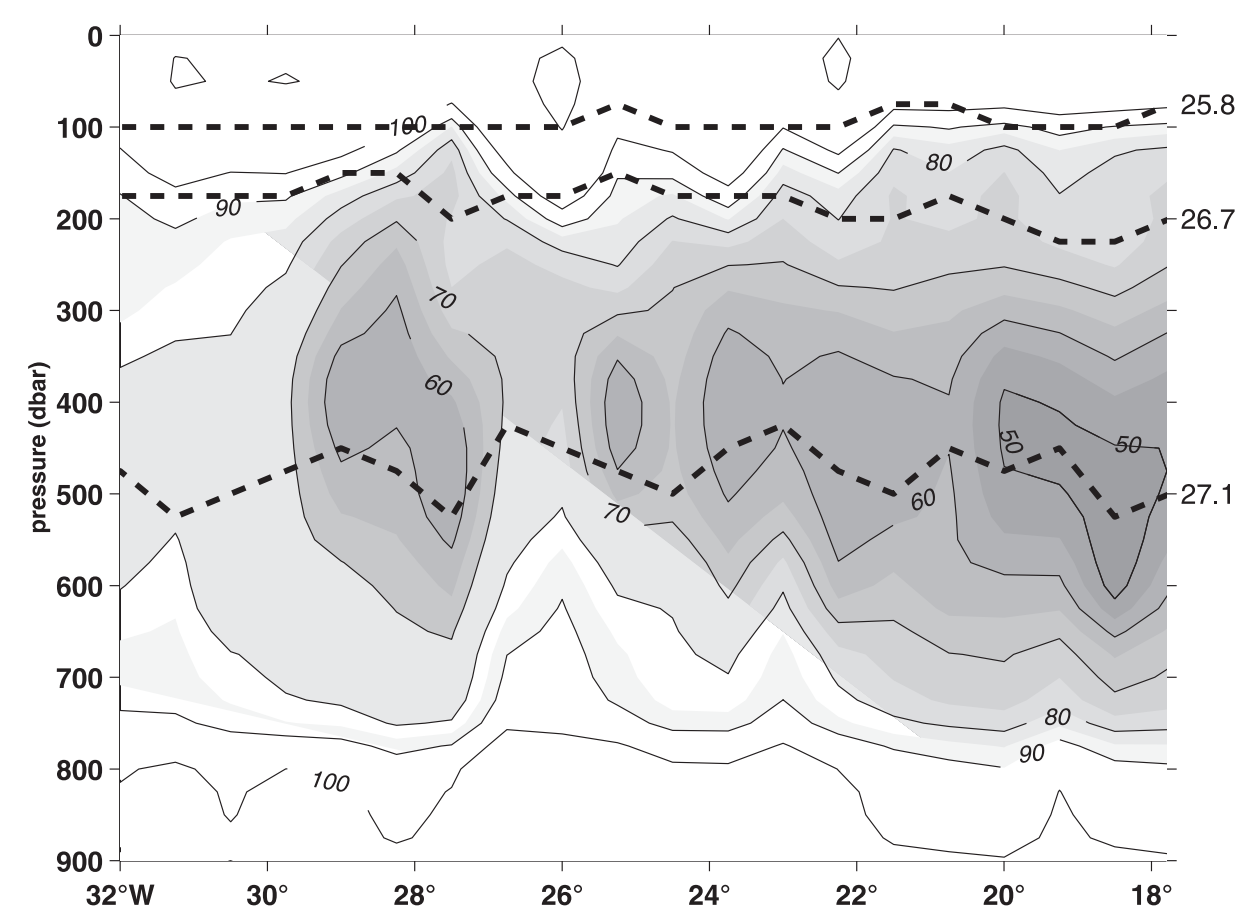

Figure 7. Oxygen distribution from bottle samples $\left(\mu \mathrm{mol} \mathrm{kg}{ }^{-1}\right)$ along $14.5^{\circ} \mathrm{N}$ in February/March 1989. Water mass boundaries (dashed black lines) are shown by the isopycnals $\sigma_{\theta}=25.8$ and $27.1 \mathrm{~kg} \mathrm{~m}^{-3}$, while $26.7 \mathrm{~kg} \mathrm{~m}^{-3}$ represents an additional potential density surface in the Central Water.

Islands. This further indicates the presence of the closed circulation cell in this area which prevents the floats to progressing into this area.

[31] Only one float drifting at 400-m depth entered the region south of the Cape Verde Islands (Figure 8). It was carried by the northern SEC from $17.5^{\circ} \mathrm{W}$ to $26^{\circ} \mathrm{W}$ near $3^{\circ} \mathrm{N}$. At $26^{\circ} \mathrm{W}$ the float entered the eastward flowing NEUC and drifted toward the African continent at $5-6^{\circ} \mathrm{N}$. This float shows the existence of a continuous NEUC flow in the tropical eastern North Atlantic as a supply path for the OMZ. Another $400 \mathrm{~m}$ float was deployed in February 2007 north of the Cape Verde Islands and moved in the deeper NEC layer westward.

[32] The ADCP current vectors, color-coded by the corresponding dissolved oxygen values at 200-m depth, from the different ship sections (Figure 9a) are associated with high oxygen values in the inflow region of the two NECC bands. These can be traced to the southeastward section off the coast of Africa taken in November 2002. At $11-12^{\circ} \mathrm{N}$ near $18^{\circ} \mathrm{W}$ the oxygen-rich water flows northward and forms an oxygen rich patch. This patch is isolated by lower values of the southeastward leg near $18^{\circ} \mathrm{W}$ from the oxygen-rich waters near $9^{\circ} \mathrm{N}$ seen in the meridional sections further to the west. This could be either because the sections are not synoptic or because eddies do play a role in oxygen fluxes in the region. The lowest oxygen values at 200-m depth are observed in the region east of the Cape Verde Islands in the $18^{\circ} \mathrm{N}$ section in a northward flow component near the African shelf and in a southward flow band at $19-20^{\circ} \mathrm{W}$, located in the circulation cell east of the Cape Verde Islands.

[33] At 400-m depth (Figure 9b) the velocity/oxygen distribution shows reduced oxygen values when compared to the 200-m depth layer in the NECC region. The region of the lowest oxygen values shifts from the Cape Verde region to the Guinea Dome region. The NEUC band as part of the southern NECC band is not present in the July 2006 cruise along $23^{\circ} \mathrm{W}$ and might not be well recognizable during the entire year. The eastward flow across the southeastward section off Africa in November 2002 at $400 \mathrm{~m}$ is much weaker than at 200-m depth and shows a reduced eastward supply which makes it possible that the low-oxygen zone off Africa is maintained. At $400-\mathrm{m}$ depth at $18^{\circ} \mathrm{N}$ similar to the $200 \mathrm{~m}$ level a northward flow component is present near the African shelf as well as a southward flow at $19-20^{\circ} \mathrm{W}$, connected to low oxygen values.

\subsection{Seasonal Variations in the OMZ}

[34] The NECC has a strong seasonal cycle [e.g., Fonseca et al., 2004]; therefore it is worth looking at the seasonal changes in the OMZ. Monthly mean oxygen values calculated from the hydrobase data set [Curry, 1996] and defined for the 200-m and 400-m depth levels and the longitudinal ranges between $20^{\circ} \mathrm{W}$ and $24^{\circ} \mathrm{W}$ are used to compare the inflow region $5^{\circ} \mathrm{N}$ to $10^{\circ} \mathrm{N}$ and the recirculation region $10^{\circ} \mathrm{N}$ to $14^{\circ} \mathrm{N}$ (Figure 10; for data obtained since 1961).

[35] At 200-m depth, the monthly distributions shows an oxygen content in the inflow region at $5-10^{\circ} \mathrm{N}$ that is higher by about $20 \mu \mathrm{mol} \mathrm{kg}{ }^{-1}$ for the 11 months available compared to the recirculation region north of $10^{\circ} \mathrm{N}$. The oxygen content in the inflow region is lowest in February and the oxygen difference to the region north of $10^{\circ} \mathrm{N}$ is smallest in February. The lower oxygen content in the inflow region from January to April reflects the weakening of the NECC in boreal spring. The larger difference between the southern box and the northern box in the second half of the year suggests that stronger supply of oxygen is carried 


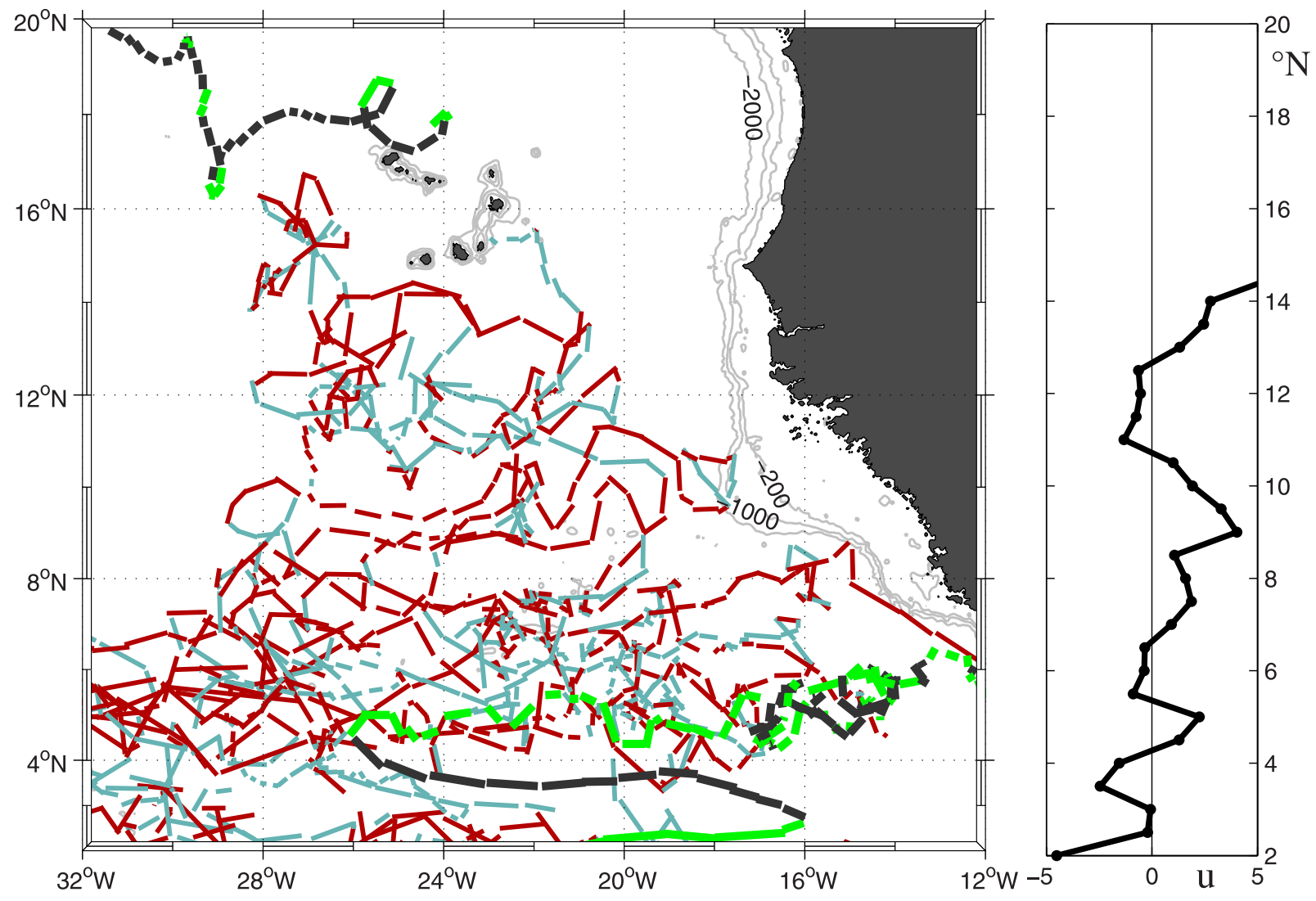

Figure 8. Trajectories of profiling APEX floats deployed since April 2000 drifting at nominal 200-m depth with eastward flow in red and westward flow in light blue. Connected is the diving position with the surfacing position, the surface drift every $9 \mathrm{~d}$ is left blank. One float drifting at nominal 400-m depth entered the study area from the south and one deployed north of the Cape Verde Islands in 2007 are shown by a thick green line for eastward flow and a dark gray line for westward flow (ARGO status: 2 October 2007). The mean 200-m float velocity in $\mathrm{cm} \mathrm{s}^{-1}$ between $18^{\circ} \mathrm{W}$ and $28^{\circ} \mathrm{W}$ south of $14.5^{\circ} \mathrm{N}$ is attached (right frame).

into the tropical eastern North Atlantic. The $10-14^{\circ} \mathrm{N}$ curve shows almost no seasonal variation; hence no time delay between the two curves can be derived.

[36] At 400-m depth the oxygen content is lower for both regions than at 200-m depth and the difference between the inflow and the recirculation region is a little smaller than at $200 \mathrm{~m}$ with a mean difference of $15 \mu \mathrm{mol} \mathrm{kg}{ }^{-1}$. The water with the higher oxygen content is brought into the eastern North Atlantic from May to November. The recirculation area shows a slight oxygen increase starting in August with maximum values in November and January, which might indicate a relation to the seasonal inflow signal with a time delay of a few months. The low oxygen values in February in both areas are based on measurements from 5 different years and there is no indication of incorrect values.

[37] In an earlier investigation of the NECC from surface drifters, current meters and ship drift for $23^{\circ} \mathrm{W}$ to $33^{\circ} \mathrm{W}$ [Richardson and Reverdin, 1987] a strong NECC with two eastward cores in July to September was observed. However, generally westward flow was described for March to May, with zero velocity at $6^{\circ} \mathrm{N}$ and a reduced westward component at $8^{\circ} \mathrm{N}$ [Richardson and Reverdin, 1987; their Figure 11]. At a subsurface isopycnal $\left(\sigma_{\theta}=25.0 \mathrm{~kg} \mathrm{~m}^{-3}\right)$ the $1 / 12^{\circ}$-FLAME model shows the two cores of the NECC for the annual mean [Stramma et al., 2005, Figure 5]. Nevertheless, the two NECC current bands may be absent in spring. At $35^{\circ} \mathrm{W}$ the output from a high resolution Ocean General Circulation Model shows two eastward cores for all four seasons, however with weaker amplitudes located below a surface layer in winter and spring [Urbano et al., 2006, Figure 2].

[38] Some insight into the seasonal changes of the NECC at 200-m depth can be gained from the floats drifting at 200$\mathrm{m}$ depths, sorted into seasons. In all four seasons (Figure 11) some floats moved eastward in the NECC region. As expected, this eastward flow is weak in December to February and is mainly located in the NECC region while in the nNECC region only short eastward components appear. During the same time period the westward flow component north of the NECC is strongest, hence the westward flow at 6 to $7^{\circ} \mathrm{N}$ indicated in Figure 12a is largest in winter and spring. In contrast with the surface drifters the $200 \mathrm{~m}$ floats indicate a year-round eastward flow of the NECC.

\section{Summary and Conclusions}

[39] Ocean oxygen changes might have substantial economic consequences, calling for intensified studies of their 

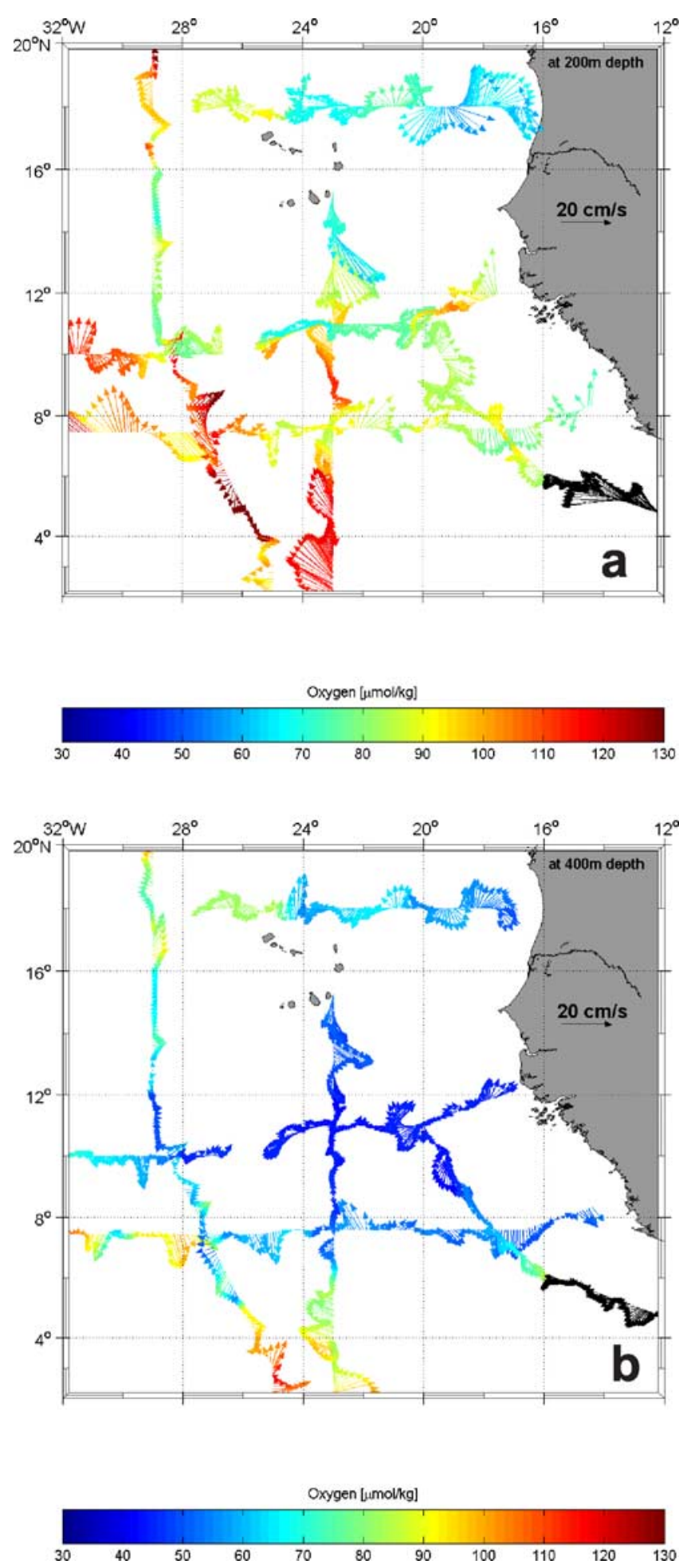

Figure 9. ADCP derived velocity vectors color coded by the corresponding dissolved oxygen values in $\mu \mathrm{mol} \mathrm{kg}^{-1}$ at (a) 200-m depth and (b) 400-m depth from ship sections at $23^{\circ} \mathrm{W}$ in July $2006,18^{\circ} \mathrm{N}$ in July 2006 , about $28^{\circ} \mathrm{W}$ in July/ August 2003, $7^{\circ} 30^{\prime} \mathrm{N}$ in February/March 1993 and 10$11^{\circ} \mathrm{N}$ as well as the southeastward leg from $11^{\circ} \mathrm{N}, 20^{\circ} \mathrm{W}$ in October/November 2002. Black vectors in the southeast are for a section without accompanying oxygen measurements. supply and maintenance, in particular under developing global-change conditions. Here the oxygen distribution of the OMZ south of the Cape Verde Islands is described from selected ship sections, and it is found that the lowest oxygen concentrations exist in the transition between Central Water and AAIW. On the basis of the large spatial velocity variability observed in the tropical eastern Atlantic it is likely that the contribution by eddy fluxes can be significant in maintaining the oxygen distribution of the OMZ, although from our data set it is not possible to quantify their contribution. The NECC and the NEUC at $4-6^{\circ} \mathrm{N}$ and the northern NECC at $8-10^{\circ} \mathrm{N}$ are clearly identified as sources of oxygen-rich water supplied to the OMZ in summer. A strong oxygen supply to the OMZ was found between 150 and $300-\mathrm{m}$ depth, while at 300 to $600-\mathrm{m}$ depth the supply is present but weak. Westward drainage of oxygen-poor water takes place north of $10^{\circ} \mathrm{N}$ through the westward flow components at and north of the Guinea Dome. The AAIW originates in the southern hemisphere and progresses northward, with the NICC as the major source of oxygen supply for the AAIW layer of the OMZ.

[40] With the floats drifting at fixed depth levels, $200 \mathrm{~m}$ and $400 \mathrm{~m}$, the horizontal distributions were also presented on depth levels instead of on isopycnal surfaces. The schematic flow fields overlain on the oxygen distribution from the hydrobase-2 data set at 200-m and 400-m depth (Figure 12) are derived from available float and section data. They are in large areas similar to the near-surface flow field (Figure 1). The oxygen distribution, however, shows quite different depth distributions.

[41] The snapshots from different months and years do not reproduce all mean current bands; nevertheless the float trajectories show that there is a mean flow field, disturbed, however, by large variability (Figure 9). At 200-m depth (Figure 12a) the eastward current bands of the NECC provide high-oxygen water to the Guinea Dome region. According to the velocity observations the NECC and NEUC shift poleward from west to east [e.g., Bourles et al., 2002]. Both the velocity and the oxygen distributions along the $28^{\circ} \mathrm{W}$ section (Figure 3), as well as the mean oxygen distribution at $200-\mathrm{m}$ depth indicate some oxygenpoor westward flow component at 200-m depth between the $\mathrm{nNECC}$ and the NECC. This is marked in Figure 12a, although its persistence and origin is largely unknown. The region southwest of the Cape Verde Islands, where a $200 \mathrm{~m}$ float stayed in the area for up to 3 years shows a local oxygen minimum confirming the presence of a stagnation area. The lowest oxygen values are located between the Cape Verde Islands and the African shelf, where a cyclonic circulation cell traps the oxygen poor water. The other area of low oxygen values is the shelf region of the African continent.

[42] At 400-m depth (Figure 12b) the zone of the lowest oxygen content shifts to the Guinea Dome region. At this deeper part of the NEUC/NECC the flow is weaker than above and carries less oxygenated water into the Guinea Dome region. North of $10^{\circ} \mathrm{N}$ a tongue of oxygen-poor water extends westward and represents the drainage of oxygen poor water from the OMZ towards the western Atlantic. Minimum values at this depth level are observed east and southeast of the Cape Verde Islands and in the westward export paths at $10-12^{\circ} \mathrm{N}$. In the northwest, the signature of 

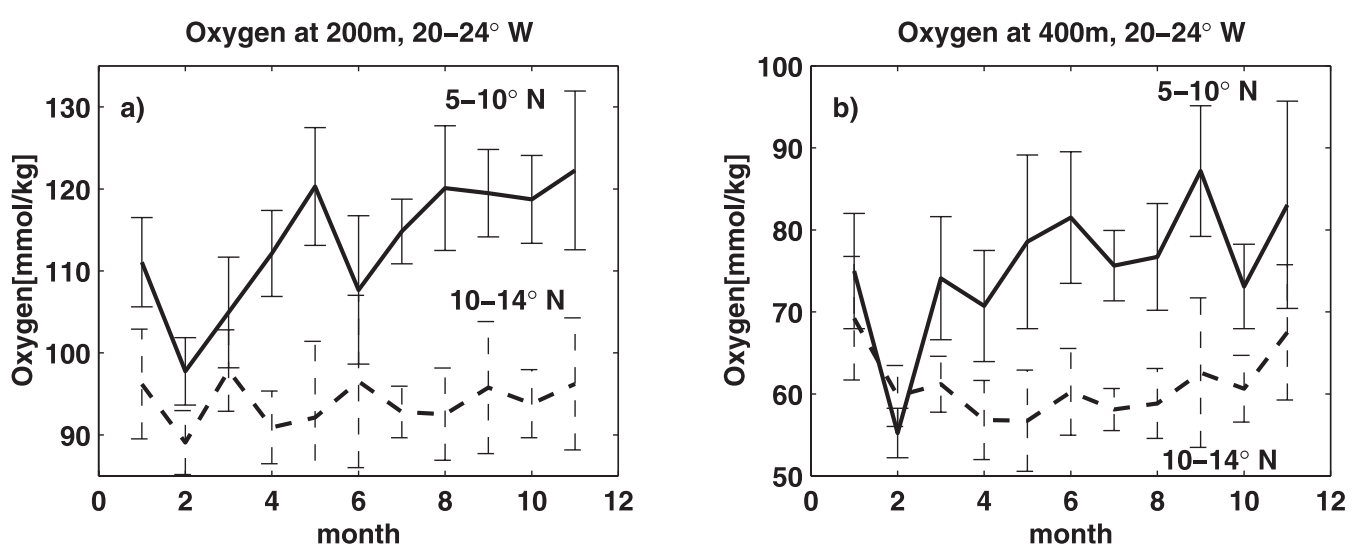

Figure 10. Mean monthly oxygen content in $\mu \mathrm{mol} \mathrm{kg} \mathrm{kg}^{-1}$ at (a) $200-\mathrm{m}$ depth and (b) 400-m depth from the hydrobase- 2 bottle and CTD data [Curry, 1996] since 1961 between 20 and $24^{\circ} \mathrm{W}$ and in the latitude range $5^{\circ} \mathrm{N}$ to $10^{\circ} \mathrm{N}$ (solid line) and $10^{\circ} \mathrm{N}$ to $14^{\circ} \mathrm{N}$ (broken line). No December values are contained in the data set. Error bars are the standard errors as standard deviation divided by the square root of the number of different years with available measurements for each month.

the NEC is shifted a little northward at 400-m depth when compared to the 200-m depth level.

[43] An unresolved question is whether the two NECC bands exist year-round and are a continuous source for oxygen-rich water. The zonal near-surface speed plot from surface drifters between 23 and $33^{\circ} \mathrm{W}$ by Lumpkin and
Garzoli [2005, Figure 13] did not show any eastward flow in the NECC area north of $5^{\circ} \mathrm{N}$ from mid-February till May and largest eastward flow with an indication of two cores from June to December. The historical oxygen data (Figure 10) indicate a reduced oxygen supply in spring. As both meridional sections used here are from the summer
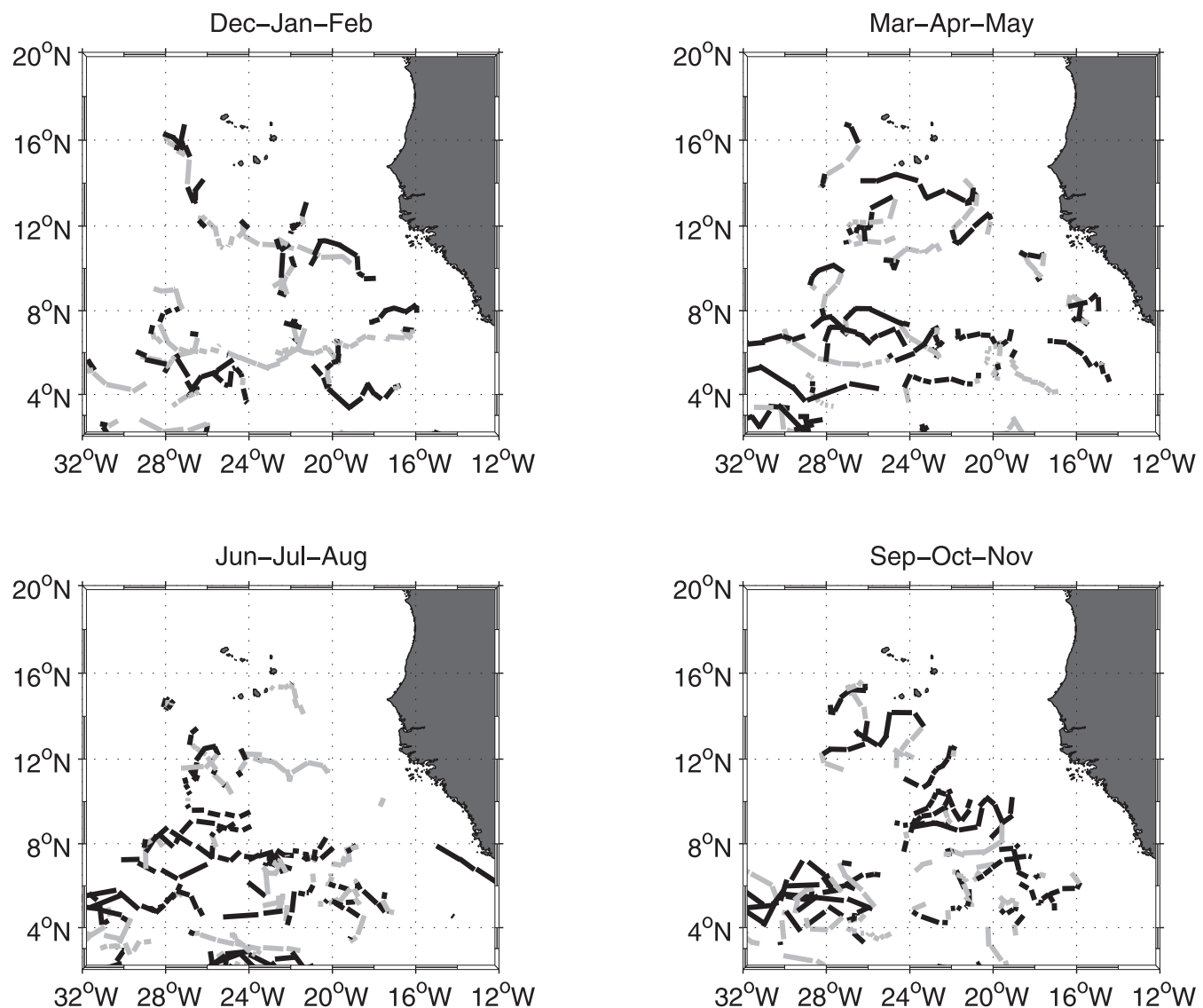

Figure 11. Trajectories of profiling APEX floats drifting at nominal 200-m depth shown in Figure 8 with eastward flow in black and westward flow in gray for the periods December to February, March to May, June to August, and September to November. 

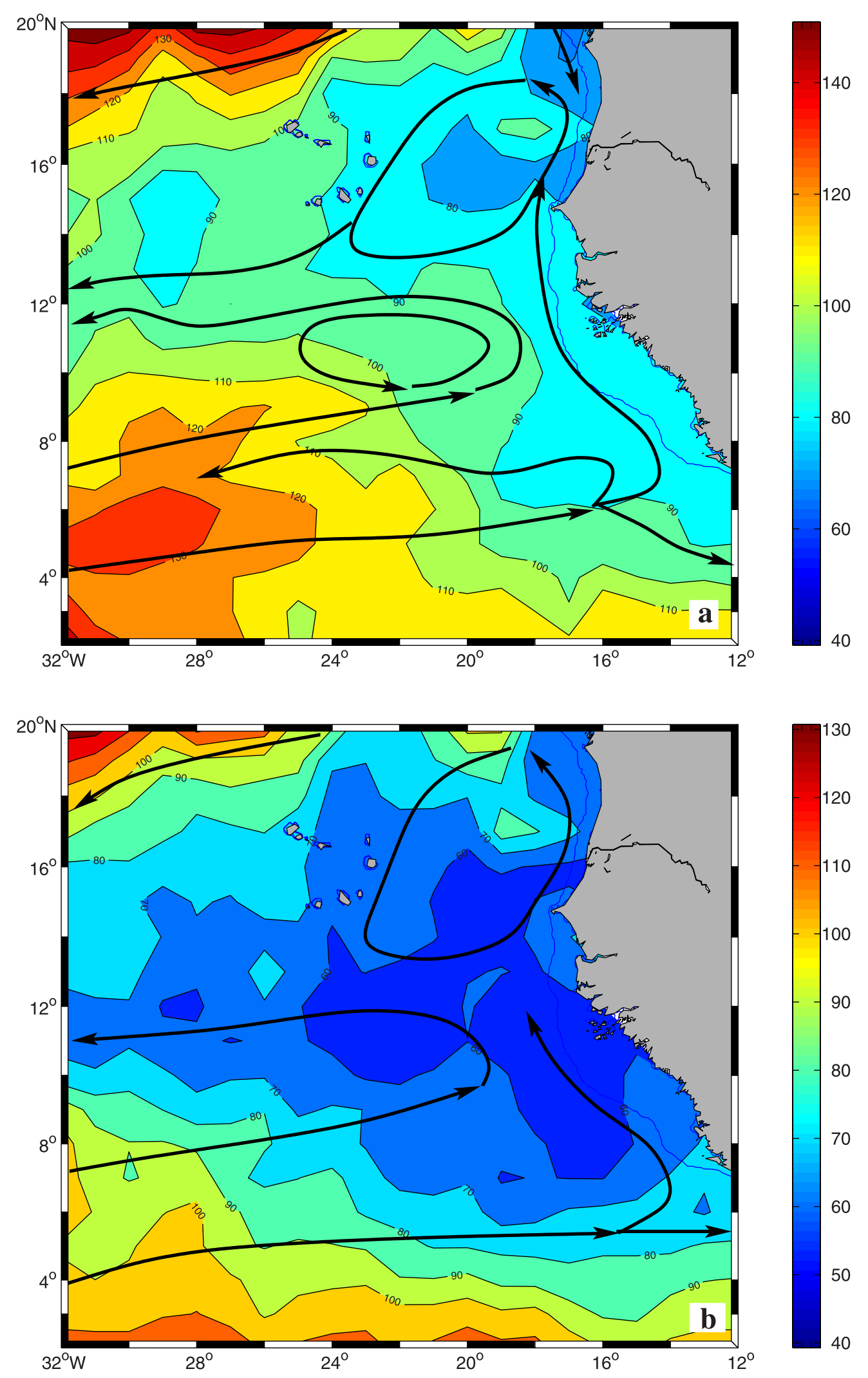

Figure 12. Circulation schematics overlain on the oxygen distribution of the hydrobase-2 bottle and CTD data [Curry, 1996] smoothed with an objective interpolation scheme at (a) 200-m depth and (b) 400-m depth. 
period we have no direct velocity observations available for the spring period. The $28^{\circ} \mathrm{W}$ section in July/August 2003 was a repeated survey of a similar section in August 1988. When computing the geostrophic velocity relative to 1250 dbar for August 1988, two NECC current bands were also found to exist between 5 and $10^{\circ} \mathrm{N}$. These currents are connected to regions of enhanced oxygen values [Tsuchiya et al., 1992, Figure 8]. Furthermore, the ADCP section of June 2005 by R/V Polarstern (Figure 6a) was too close to the summer for any detailed information on the spring situation. Different to the surface drifters the $200 \mathrm{~m}$ floats (Figure 11) indicate a year-round eastward flow of the NECC. Nevertheless, meridional sections with direct velocity observations crossing the NECC in spring are needed to resolve the vertical distribution of the spring situation of the zonal oxygen supply.

[44] The total eastward transport in July 2006 of both NECC bands for $\sigma_{\theta}<27.1 \mathrm{~kg} \mathrm{~m}^{-3}$ at $23^{\circ} \mathrm{W}$ was about $13 \mathrm{~Sv}$. The part of the NECC bands which recirculates north of about $10^{\circ} \mathrm{N}$ is called here the Guinea Dome transport although it has to be kept in mind that only a small fraction seems to recirculate in a closed circulation cell. In July 2006 the Guinea Dome transport from direct observations was 3.1 Sv for the layer from the sea surface to $\sigma_{\theta}=25.8 \mathrm{~kg} \mathrm{~m}^{-3}$ and $6.5 \mathrm{~Sv}$ for the layer $\sigma_{\theta}<27.1 \mathrm{~kg} \mathrm{~m}^{-3}$. Similar transport values were estimated for a zonal $\mathrm{R} / \mathrm{V}$ Meteor section in October/November 2002 along about $11^{\circ} \mathrm{N}$ of $2.8 \mathrm{~Sv}$ for the layer $\sigma_{\theta}<25.8 \mathrm{~kg} \mathrm{~m}^{-3}$ and $6.8 \mathrm{~Sv}$ for the layer $\sigma_{\theta}<27.1 \mathrm{~kg} \mathrm{~m}^{-3}$ layer [Stramma et al., 2005]. The total Guinea Dome transport from the ADCP observations at $23^{\circ} \mathrm{W}$ in July 2006 was about $6.5 \mathrm{~Sv}$ above $\sigma_{\theta}=27.1 \mathrm{~kg} \mathrm{~m}^{-3}$. Hence about half of the total NECC transport circulates in the Guinea Dome and recirculates to the north of the dome, while the other half must be transported northward or southeastward near the African continent.

[45] The vertical distribution of the large-scale horizontal flow field in the upper $400 \mathrm{~m}$ stays similar in most regions presented here; however, the vertical oxygen distribution shows large variations. At 200-m depth the oxygen supply by the NECC bands is high and in the Guinea Dome region the oxygen values are larger than east of Cape Verde Islands and near the African shelf. The low oxygen water east of the Cape Verde Islands is trapped in a cyclonic circulation cell. At $400-m$ depth the oxygen supply by the NEUC and NECC toward the Guinea Dome region is weak, and together with a weak and variably flow field the open ocean oxygen minimum is located at 400-m depth in the Guinea Dome region. In addition the oxygen distribution is low near the African shelf. At 400 to 600-m depth the westward export of oxygen poor water can be observed at $10^{\circ} \mathrm{N}-$ $12^{\circ} \mathrm{N}$. In summary, the NECC and NEUC provide oxygenrich water to the OMZ of the eastern tropical North Atlantic, especially in the depth range around $200 \mathrm{~m}$ in summer and fall, while in winter and spring oxygen-rich water seems to be supplied by a weak and variable NECC/NEUC. Future direct current observations are needed especially for a better description of the winter and spring seasons.

[46] Acknowledgments. Financial support for LS, PB, JS, and AK was received through the IFM-GEOMAR as well the Deutsche Forschungsgemeinschaft (DFG) as part of the cruise funding of Meteor M68/2 and M68/3 and of the SFB 754. Financial support for JF and FS was received through the Bundesministerium für Forschung und Technologie for the
German Argo project. The NOAA ship R/V Ronald H. Brown 2003 cruise (chief scientists John Bullister and Nicolas Gruber) was completed under the NSF/NOAA funded Repeat Hydrography Program and data (ADCP P.I. Eric Firing and Julia M. Hummon and hydrography P.I. Gregory Johnson) were made available through the CLIVAR and Carbon Hydrographic Data Office, La Jolla, California, USA). Some float data were collected and made freely available by the international Argo Project and the national programs that contribute to it (http://www.argo.ucsd.edu). Verena Hormann, Sunke Schmidt, and John Jeschewskie helped with the data processing. We thank Walter Zenk for allocating shipboard ADCP data.

\section{References}

Arhan, M., H. Mercier, B. Bourles, and Y. Gouriou (1998), Hydrographic sections across the Atlantic at $7^{\circ} 30^{\prime} \mathrm{N}$ and $4^{\circ} 30^{\prime} \mathrm{S}$, Deep Sea Res. I, 45, $829-872$.

Bourles, B., M. D'Orgeville, G. Eldin, Y. Gouriou, R. Chuchla, Y. DuPenhoat, and S. Arnault (2002), On the evolution of the thermocline and subthermocline eastward currents in the Equatorial Atlantic, Geophys. Res. Lett., 29(16), 1785, doi:10.1029/2002GL015098.

Brandt, P., F. A. Schott, C. Provost, A. Kartavtseff, V. Hormann, B. Bourles, and J. Fischer (2006), Circulation in the central equatorial Atlantic: Mean and intraseasonal to seasonal variability, Geophys. Res. Lett., 33, L07609, doi:10.1029/2005GL025498.

Curry, R. (1996), HydroBase - A database of hydrographic profiles and tools for climatological analysis, Tech. Rep. WHOI-96-01, 50 pp., Woods Hole Oceanogr. Inst., Woods Hole, Mass.

Elmoussaoui, A., M. Arhan, and A. M. Treguier (2005), Model-inferred upper ocean circulation in the eastern tropics of he North Atlantic, Deep Sea Res. I, 52, 1093-1120.

Fonseca, C. A., G. J. Goni, W. E. Johns, and E. J. D. Campos (2004), Investigation of the North Brazil Current retroflection and North Equatorial Countercurrent variability, Geophys. Res. Lett., 31, L21304, doi:10.1029/2004GL020054.

Fratantoni, D. M. (2001), North Atlantic surface circulation during the 1990's observed with satellite-tracked drifters, J. Geophys. Res., 106(C10), 22,067-22,093.

Garcia, H., A. Cruzado, L. Gordon, and J. Escanez (1998), Decadal-scale chemical variability in the subtropical North Atlantic deduced from nutrient and oxygen data, J. Geophys. Res., 103(C2), 2817-2830.

Garzoli, S. L., and E. J. Katz (1983), The forced annual reversal of the Atlantic North Equatorial Countercurrent, J. Phys. Oceanogr., 13, $2082-$ 2090

Hagen, E. (2001), Northwest African upwelling scenario, Oceanologica Acta, 24, suppl., S113-S128.

Johnson, G. C., and N. Gruber (2007), Decadal water mass variations along $20^{\circ} \mathrm{W}$ in the northeastern Atlantic Ocean, Prog. Oceanogr., 73, 277-295.

Joos, F., G.-K. Plattner, T. F. Stocker, A. Körtzinger, and D. W. R. Wallace (2003), Trends in marine dissolved oxygen: Implications for ocean circulation changes and the carbon budget, Eos Trans. AGU, 84, 197-204.

Karstensen, J., L. Stramma, and M. Visbeck (2008), The oxygen minimum zones in the eastern tropical Atlantic and Pacific Oceans, Prog. Oceanogr, in press.

Keeling, R. F., and H. Garcia (2002), The change in oceanic $\mathrm{O}_{2}$ inventory associated with recent global warming, Proc. Natl. Acad. Sci. U.S.A., 99, $7848-7853$

Klein, B., R. L. Molinari, T. J. Müller, and G. Siedler (1995), A transatlantic section at $14.5 \mathrm{~N}$ : Meridional volume and heat fluxes, J. Mar. Res., 53, 929-957.

Lazaro, C., M. J. Fernandes, A. M. P. Santos, and P. Oliveira (2005), Seasonal and interannual variability of surface circulation in the Cape Verde region from 8 years of merged T7P and ERS-2 altimeter data, Remote Sens. Environ., 98, 45-62.

Lumpkin, R., and S. L. Garzoli (2005), Near-surface circulation in the tropical Atlantic Ocean, Deep Sea Res. I, 52, 495-518.

Luyten, J. R., J. Pedlosky, and H. Stommel (1983), The ventilated thermocline, J. Phys. Oceanogr., 13, 292-309.

Marin, F., and Y. Gouriou (2000), Heat fluxes across $7^{\circ} 30^{\prime} \mathrm{N}$ and $4^{\circ} 30^{\prime} \mathrm{S}$ in the Atlantic Ocean, Deep Sea Res., I, 47, 2111-2139.

Matear, R. J., and A. C. Hirst (2003), Long-term changes in dissolved oxygen concentrations in the ocean caused by protracted global warming, Global Biogeochem. Cycles, 17(4), 1125, doi:10.1029/2002GB001997.

Mayer, D. A., and R. H. Weisberg (1993), A description of COADS surface meteorological fields and the implied Sverdrup transports for the Atlantic Ocean from $30^{\circ} \mathrm{S}$ to $60^{\circ} \mathrm{N}, J$. Phys. Oceanogr., 23, 2201-2221.

Mittelstaedt, E. (1983), The upwelling area off Northwest Africa - A description of phenomena related to coastal upwelling, Prog. Oceanogr., 12, 307-331.

Mittelstaedt, E. (1991), The ocean boundary along the northwest African coast: Circulation and oceanographic properties at the sea surface, Prog. Oceanogr., 26, 307-355. 
Morrison, J. M., et al. (1999), The oxygen minimum zone in the Arabian Sea during 1995, Deep Sea Res. II, 46, 1903-1931.

Ollitrault, M., M. Lankhorst, D. Fratantoni, P. Richardson, and W. Zenk (2006), Zonal intermediate currents in the equatorial Atlantic Ocean, Geophys. Res. Lett., 33, L05605, doi:10.1029/2005GL025368.

Rabalais, N. N., and R. E. Turner (2001), Hypoxia in the northern Gulf of Mexico: Description, causes and change, in Coastal Hypoxia: Consequences for Living Resources and Ecosystems, Coastal Estuarine Stud., vol. 58, edited by N. N. Rabalais, and R. E. Turner, pp. 1-36, AGU, Washington, D. C.

Richardson, P. L., and G. Reverdin (1987), Seasonal cycle of velocity in the Atlantic North Equatorial Countercurrent as measured by surface drifters, current meters, and ship drift, J. Geophys. Res., 92(C4), 3691-3708.

Schouten, M. W., R. P. Matano, and T. P. Strub (2005), A description of the seasonal cycle of the equatorial Atlantic from altimeter data, Deep Sea Res. I, 52, 477-493.

Schott, F. A., and C. W. Böning (1991), The WOCE model in the western equatorial Atlantic: Upper layer circulation, J. Geophys. Res., 96, 69937004.

Schott, F., P. Brandt, M. Hamann, J. Fischer, and L. Stramma (2002), On the boundary flow off Brazil at $5-10^{\circ} \mathrm{S}$ and its connection to the interior tropical Atlantic, Geophys. Res. Lett., 29(17), 1840, doi:10.1029/2002GL014786.

Schott, F. A., J. P. McCreary, and G. C. Johnson (2004), Shallow overturning circulation of the tropical-subtropical oceans, in Earth's Climate: The Ocean Atmosphere Interaction, edited by C. Wang, S.-P. Xie, and J. A. Carton, pp. 261-304, AGU, Washington, D. C.

Siedler, G., and R. Onken (1996), Eastern recirculation, in The Warmwatersphere of the North Atlantic Ocean, edited by W. Krauss, pp. 339-364, Gebr. Bornträger Berlin-Stuttgart, Berlin.
Siedler, G., N. Zangenberg, R. Onken, and A. Morliere (1992), Seasonal changes in the tropical Atlantic circulation: Observations and simulations of the Guinea Dome, J. Geophys. Res., 97, 703-715.

Stramma, L., and F. Schott (1999), The mean flow field of the tropical Atlantic Ocean, Deep Sea Res. II, 46, 279-303.

Stramma, L., J. Fischer, P. Brandt, and F. Schott (2003), Circulation, variability and near-equatorial meridional flow in the central tropical Atlantic, in Interhemispheric Water Exchange in the Atlantic Ocean, Oceanogr Ser., vol. 68, edited by G. J. Goni, and P. Malanotte-Rizzoli, pp. 1-22, Elsevier, New York.

Stramma, L., S. Hüttl, and J. Schafstall (2005), Water masses and currents in the upper tropical Northeast Atlantic off northwest Africa, J. Geophys. Res., 110, C12006, doi:10.1029/2005JC002939.

Tsuchiya, M., L. D. Talley, and M. S. McCartney (1992), An eastern Atlantic section from Iceland southward across the equator, Deep Sea Res. I, 39, 1885-1917.

Urbano, D. F., M. Jochum, and I. C. A. da Silveira (2006), Rediscovering the second core of the Atlantic NECC, Ocean Modell., 12, 1-15.

Wallace, D. R., and H. W. Bange (2004), Introduction to special section: Results of the Meteor 55: Tropical SOLAS expedition, Geophys. Res. Lett., 31, L23S01, doi:10.1029/2004GL021014.

P. Brandt, J. Fischer, A. Körtzinger, J. Schafstall, F. Schott, and L. Stramma, Leibniz-Institut für Meereswissenschaften an der Universität Kiel, IFM-GEOMAR, D-24105 Kiel, Germany. (1stramma@ifm-geomar.de) 